\title{
Guerra submarina en España (1914-1918)
}

\author{
Jesús Perea Ruiz
}

\begin{abstract}
RESUMEN
Durante la primera guerra mundial los Gobiernos españoles mantuvieron la neutralidad, que fue benévola hacia uno u otro bando beligerante según las inclinaciones de los responsables de turno y fueron éstas contrarrestadas por la opinión pública o por las directrices de Alfonso XIII. Esta neutralidad fue defendida con ardor por los alemanes y en cierto modo también por los aliados, sin embargo, en España se temió una ruptura de relaciones, fundamentalmente con las Potencias Centrales, por los ataques de sus submarinos contra los barcos mercantes españoles que suministraban productos considerados contrabando de guerra y cruzaban zonas marítimas que los alemanes acotaron para evitar los abundantes suministros que recibía Inglaterra del exterior. En este artículo, que está basado en la correspondencia diplomática del Ministerio de Asuntos Exteriores del Imperio alemán, se describen los temores de su Embajador en Madrid, Príncipe de Ratibor, por la pérdida de la neutralidad, motivados por la orientación aliadófila del que fue durante un cierto tiempo presidente del Consejo de Ministros, Conde de Romanones.
\end{abstract}

PALABRAS CLAVE

Relaciones diplomáticas, primera guerra mundial, submarinos, Romanones, Ratibor.

\section{ABSTRACT}

During World War I, the Spanish Governments maintained their neutrality that was benevolent toward one or another belligerent side, according to the inclinations of the responsibles on duty, and were counteracted by the public opinion or the guidelines of Alfonso XIII. This neutrality was defended strongly by the Germans and in a certain way also by the allies, however in Spain a break of the relationships was feared, fundamentally with the Central Powers, due to the attacks of submarines against Spanish merchant ships that supplied goods considered as war contraband and that were crossing marine areas that the Germans had established to avoid the abundant supplies that England received from the exterior. In this article, that is based on the diplomatic correspondence of the Ministry of Foreign Affairs of the German empire, there will be described the fears of its Ambassador in Madrid, Prince of Ratibor, of a possible loss of neutrality, based in the pro-allied orientation of the "Conde de Romanones", who was during a certain time the President of the Council of Ministers.

\section{KEY WORDS}

Diplomatic relations, first world war, submarines, Romanones, Ratibor 
Durante la Primera Guerra Mundial, España permaneció al margen del conflicto como mero espectador, soportando las presiones de los beligerantes, pero convencida de que en una intervención directa los perjuicios serían muy superiores a los logros que se pudieran conseguir.

La guerra (1914-1918) se desarrolló principalmente en el escenario del continente europeo. Los ejércitos imperiales, el alemán y el austro-húngaro, iniciaron los combates en dos frentes, el occidental con el ataque a Francia a través de Bélgica y en el oriental con la invasión de Rusia. Confiaron en una victoria rápida, pero la realidad fue otra, los ejércitos aliados resistieron, los frentes se estabilizaron y comenzó una guerra de desgaste que duró hasta que, después de la paz con la nueva república soviética, los franceses con la ayuda de ingleses y americanos lograron romper las líneas alemanas y conseguir la victoria.

En el mar se dio una circunstancia parecida. En la gran batalla de Skagerrak, también llamada de Jutlandia, se enfrentaron las armadas alemana e inglesa el 31 de mayo de 1916. En el combate los ingleses sufrieron mayores pérdidas que los alemanes, pero su superioridad en número de unidades navales obligó a éstos a retirarse a sus bases del mar del Norte. Ambas flotas evitaron en el futuro nuevos enfrentamientos, la alemana quedó retenida en sus aguas, mientras que la inglesa mantuvo su libertad de acción en todos los mares. Ante esta dificultad, los alemanes forzaron la construcción de submarinos con la idea de bloquear a su vez las costas británicas y evitar los suministros de material de guerra y productos básicos para la población civil inglesa.

España se vio involucrada en esta fase de la guerra. Gran parte de su intercambio comercial estaba orientado hacia las Islas Británicas, en cuyas aguas los alemanes, en un momento crucial de la guerra, atacaron a todo barco de bandera beligerante o neutral, siendo víctimas de estos ataques numerosos barcos españoles. Esto provocó no solamente la pérdida de dichos barcos y en ocasiones de la tripulación, sino la disminución del tráfico marítimo que ocasionó graves dificultades a España en la exportación de minerales y fruta e importación de carbón. La situación angustiosa, que se manifestó en los países beligerantes en la última fase de la guerra, también tuvo su eco en España ocasionando graves crisis tanto en los gobiernos como en la ciudadania y originando una amenaza constante de romper las relaciones con las potencias centrales.

\section{ESPAÑA ANTE LA DECLARACIÓN DE GUERRA}

Las relaciones entre España y Alemania habían sido escasas antes del año 1914. Las primeras negociaciones de importancia tuvieron lugar cuando Alemania en 1898 compró los archipiélagos de Marianas, Carolinas y Palaos en el Océano Pacífico. Los vínculos dinásticos no jugaron un papel im- 
portante, aunque sí ayudaron a mantener ciertos afectos, no en vano la madre de Alfonso XIII, María Cristina, pertenecía a la casa de Habsburgo que regía el Imperio Austro-húngaro y su esposa, Victoria Eugenia, era nieta de la reina Victoria de Inglaterra y prima del Emperador Guillermo II de Alemania. El Rey, en sus sentimientos más íntimos, dio la sensación a juzgar por sus conversaciones con personas de confianza que amaba a Francia, odiaba a Inglaterra y admiraba a Alemania.

A partir de marzo de 1910 el Embajador de Alemania en Madrid, príncipe Max de Ratibor (1856-1924), fue uno de los protagonistas de las relaciones entre España y Alemania hasta el final de la guerra en 1918. En España, en aquel entonces, ya había una numerosa colonia de alemanes dedicados al comercio, importación de artículos manufacturados, explotación de minas, fabricación de maquinaria y de productos químicos. Algunos miembros de esta colonia se esforzaron en incrementar el conocimiento mutuo entre ambos países y especialmente en conseguir un mayor intercambio de información. Durante el primer periodo, hasta el año 1916, su actividad se centró en adquirir una agencia de noticias fiable, ya que la más importante, Fabra, dependía de la francesa Havas que filtraba sus noticias, eliminando las que favorecían a Alemania. Mientras la guerra no obligó al Gobierno alemán a intervenir directamente, las actividades informativas de origen alemán estuvieron en manos de particulares, fundamentalmente de:

- August Hofer, con sede en Barcelona, director de Neufville, fabricante de maquinaria de artes gráficas y filial de una empresa de Frankfurt, que fundó una agencia de transmisión de noticias y comentarios periodísticos que distribuía entre casi todos los periódicos de España, que eran clientes suyos.

- Los directores de la filial de AEG en Madrid, Armbruster y Rautzenberg, que suministraban material periodístico a 178 periódicos españoles.

- Carl Coppel, propietario de una fábrica de relojes en Madrid, que publicaba cada quince días un folleto titulado Por la patria y por la verdad cuya tirada llegó a los 40.000 ejemplares. ${ }^{1}$

En Europa, se desarrollaron una serie de crisis en la zona de los Balcanes entre los años 1906 y 1913 como consecuencia del retroceso de la influencia turca y las ambiciones imperialistas y nacionalistas de los países emergentes. El asesinato del heredero del trono austriaco, archiduque Francisco Fernando, fue la chispa que desencadenó en 1914 una serie de declaraciones de guerra que desembocaron en la primera guerra mundial. El 1 de agosto Alemania declaró la guerra a Rusia y el 3 a Francia, invadiendo ese 
mismo día Bélgica para atacar a Francia por el norte y conseguir una rápida rendición, sin embargo, Inglaterra no se quedó inactiva y movilizó su flota para defender las costas del mar del Norte.

Los españoles decidieron mantenerse a la expectativa. Su fuerza militar era insignificante comparada con la de las potencias en lucha y su situación geográfica estaba muy alejada de los campos de batalla. Una intervención activa en la contienda sólo podía reportar ventajas territoriales a cambio de enormes sacrificios y las únicas ambiciones de España en aquel momento eran la reconquista de Gibraltar, el dominio de Tánger y una mayor influencia sobre Portugal y el territorio marroquí, empresas a lograr a costa de Francia e Inglaterra, lo que presuponía la victoria de Alemania.

Al comienzo de la guerra la mayoría de los dirigentes políticos españoles y muy especialmente el entonces su Jefe de Gobierno, Eduardo Dato, se decantó por mantener la neutralidad. Solamente Romanones lanzó un globo sonda para ver la reacción de la opinión pública. El Conde comentó en sus Memorias: «yo no entendí nunca que España debiera ser beligerante. Para entrar en la colosal contienda, no existía motivo justificado, pero sí para permanecer, no en una neutralidad neutra, sino en una neutralidad francamente inclinada a las naciones occidentales». ${ }^{2}$

La opinión pública española se dividió en dos bandos: germanófilos y aliadófilos ${ }^{3}$ y sus manifestaciones se vieron perfectamente reflejadas en la prensa. Para la derecha social y política, germanófilos, Alemania representaba el orden y la autoridad. A este grupo pertenecían desde los carlistas hasta los conservadores del Gobierno, los personajes de la Corte, el clero, los terratenientes, los altos funcionarios, una parte de los hombres de negocios y la mayor parte de los oficiales del Ejército y de la Marina. Para la izquierda, en cambio, al lado de Francia e Inglaterra estaban la causa del derecho, la libertad, la razón y el progreso como decía Lerroux, el más destacado de los intervencionistas. Los francófilos se repartían desde los liberales monárquicos y los republicanos hasta los socialistas y los sindicalistas de extrema izquierda. A éstos se unían la mayor parte de los intelectuales, la clase trabajadora, la clase media ilustrada, la clase media de las finanzas y de la industria y una pequeña parte del Ejército.

La guerra no se desarrolló según los planes alemanes. Del 6 al 9 de septiembre en la batalla del Marne los franceses detuvieron el avance alemán y en octubre la guerra de movimientos se convirtió en guerra de posiciones. Grandes batallas como la de Yprès, en la que por primera vez se emplearon gases tóxicos, la de Verdún, donde las enormes pérdidas humanas detuvieron la lucha y la del Somme, fracaso anglo francés de intentar romper el

${ }^{2}$ Romanones, Conde de, Las responsabilidades políticas del antiguo régimen. Plus Ultra, Madrid 1949, p. 77

${ }^{3}$ Para más información ver: DiAZ-PLAJA, Fernando. Francófilos y germanófilos. Dopesa, Barcelona, 1973. 
frente enemigo, no consiguieron mover apenas las líneas de combate. En el frente oriental después de las brillantes victorias del general Hindenburg en las batallas de Tannenberg y los Lagos Masurianos, el frente fue avanzando durante el año 1915 hasta detenerse con la llegada del invierno. En el mar fue derrotada una escuadra alemana en las islas Malvinas (8-12-1914), pero la batalla decisiva tuvo lugar el 31 de mayo de 1916 en las inmediaciones del estrecho de Skagerrak, en la que ambas flotas sufrieron tales pérdidas que decidieron evitar todo enfrentamiento posterior y mantener sus posiciones fijas. Los ingleses establecieron una rigurosa vigilancia naval entre Noruega y las islas Shetland, así como a ambos extremos del canal de la Mancha para impedir la salida de los barcos de superficie alemanes al Océano Atlántico. Los submarinos, pensados en un primer momento para apoyo y defensa de las costas belga y francesa de los territorios ocupados, se convirtieron en las únicas unidades capaces de burlar el bloqueo inglés y proseguir la batalla en el mar. Esta nueva estrategia dio origen a diversas interpretaciones sobre los acuerdos que se habían tomado para que la guerra naval se desarrollase de una forma más humana, especialmente en su relación con los países neutrales.

Cuando se convocó, el 30 de abril de 1898 por el conde de Mouravieff, la asamblea de la paz de La Haya, figuraba en el cuarto tema la licitud del empleo del torpedero submarino en las guerras marítimas. Cinco naciones, entre las que figuraban Alemania e Inglaterra, votaron aceptando la prohibición, si el acuerdo resultase unánime; nueve países, entre ellos España, se manifestaron en contra, distinguiéndose por su resuelta actitud los delegados de Holanda, Noruega, Suecia y Turquía, mantenedores del criterio de que los torpederos submarinos significaban una defensa eficaz de las costas, a la cual «no podía renunciarse y, menos que nadie, los pequeños Estados».

En España la opinión mayoritaria quedó reflejada en un comentario del diario ABC:

«El desprestigio del submarino que pudiera deducirse arbitrariamente de la circunstancia de negarle las ventajas y consideraciones de que gozan los buques de guerra, es un tema bastante más trascendental o delicado de lo que algunos suponen. En primer lugar, es un arma que tienen en abundancia todas las Marinas del mundo, señal de que la estiman lícita y nosotros mismos tenemos una ley que dispuso la construcción de esta clase de barcos con la anuencia de todos los sectores de la opinión nacional. El submarino es el recurso predilecto de los humildes, de los pueblos que, aspirando a la defensiva, sólo aceptarían la ofensiva para reivindicar sus derechos posiblemente ultrajados». 4

${ }^{4}$ Barbastro, José. $A B C$, 2-7-1916, p. 3 
Los ingleses consideraban que los submarinos dadas sus características distintas a los navíos de superficie al poder permanecer en el mar en estado de inmersión, ocultos a todo control o vigilancia y no poder ser identificada su nacionalidad o pertenencia a una potencia beligerante o neutral, no podían acogerse a las mismas normas que los barcos de superficie, por lo tanto, submarinos de estados combatientes que intentasen utilizar las aguas de los países neutrales deberían ser rechazados o internados 5 . El Gobierno español adoptó una actitud reservada. El Ministro de Marina, Augusto Miranda, defendió su posición, contraria a la de Inglaterra, de conceder los mismos derechos a los submarinos que a los barcos de superficie, por otra parte el Jefe de Estado Mayor, general Weyler, que compartía la misma opinión, veía que peligraba su política de construir submarinos en el caso de ceder ante las posturas inglesas. ${ }^{6}$

Previas a la guerra hubo varias declaraciones de derecho naval con respecto al transporte de mercancías en tiempo de conflictos. La declaración de París de 1856 en la que se prohibía la guerra de corso, se establecía que la bandera protegía la carga enemiga, exceptuando el contrabando de guerra y que no se podían confiscar los bienes de estados neutrales transportados por barcos enemigos, salvo si se trataba de contrabando de guerra. EI XIII Convenio de La Haya del 18 de octubre de 1907 fijaba normas de conducta relativas a los derechos y deberes de las potencias neutrales en caso de guerra marítima. Permitía a los barcos de potencias beligerantes permanecer en puerto neutral para reparar las averías, pero teniendo que abandonarlo a las veinticuatro horas de estar en condiciones de navegar, no podrán avituallarse más que para completar su aprovisionamiento normal en tiempo de paz y tampoco tomar más combustible que el que necesiten para llegar al puerto más próximo de su propio país.

El 24 de noviembre de 1914 el Gobierno español ratificó este Convenio, obligando a todas las autoridades y funcionarios del Estado, provinciales y municipales a ajustar su conducta a sus preceptos hasta el restablecimiento de la paz ${ }^{7}$. La declaración de Londres de 1909, entre otros acuerdos, consideraba contrabando absoluto de guerra a toda clase de armas y municiones, contrabando condicional a los alimentos para personas y animales y ropa y calzado militares. Sin embargo, no consideraba contrabando, entre otras cosas, al algodón, lana y seda en estado natural, semillas oleaginosas, caucho, abonos y máquinas para la agricultura, minería, industria textil e imprenta. Todo contrabando sería intervenido cuando fuera dirigido al enemigo. Los barcos neutrales no podían ser destruidos, sino conducidos a puerto en donde se juzgaría la legalidad de la confiscación y sólo en caso de peli-

${ }^{5} \mathrm{RAH}$, Archivo Romanones (AR), 88/4 (5). Sin fecha, Memorandum de los Gobiernos aliados

${ }^{6}$ AA PA, Spanien 61, Bd 5. 19-7-1916. Jagow-Grünau. Archivo Militar, Freiburg MA, RM 20/467, 22-81916, Informe Krohn.

${ }^{7}$ Gaceta de Madrid. Núm 318. 24 Noviembre 1914 
gro o de huída se le podría atacar, pero poniendo a salvo a las personas y documentos. Cuando los barcos de países neutrales resultasen hundidos injustificadamente se podría exigir la correspondiente indemnización.

\section{GUERRA NAVAL EN AGUAS ESPAÑOLAS}

El 26 de agosto de 1914 tuvo lugar la primera, y prácticamente la única, violación de las aguas de soberanía española al ser atacado y hundido el trasatlántico alemán armado en corso Cáncer Wilhelm der Grosse en una ensenada de la colonia española del Río de Oro. Este barco ya había hecho las siguientes capturas: El 5 de agosto de 1914 apresó al buque pesquero inglés Jubal Cain y, después de hacer prisioneros a sus 14 tripulantes, voló el barco con dinamita. El 10 de agosto apresó al vapor inglés Galician y después de examinar su documentación y de hacer prisioneros a un teniente de artillería y a un artillero, que se dirigían a Londres procedentes de El Cabo, permitió al barco continuar su viaje, en atención a que la mayoría del pasaje eran mujeres y niños. El 14 de agosto se apoderó del vapor inglés Kaipara, de 6000 toneladas, y después de recoger a bordo al capitán y a los tripulantes, lo cañoneó hasta hundirlo. En la mañana del 16 de agosto el Kaiser Wilhelm apresó al vapor inglés Nyanga de 5.000 toneladas, a seis millas de Gran Canaria. Prisioneros a bordo el capitán y la dotación, los alemanes volaron el barco con dinamita. Estaba fondeado el Kaiser Wilhelm der Grosse en aguas territoriales españolas aprovisionándose de carbón que le solían suministrar barcos alemanes menores (Bethania, Arucas, Magdeburg y Duala), que a su vez se proveían en las islas Canarias, cuando el crucero inglés Highflyer le sorprendió y entabló combate. Ante la manifiesta superioridad de éste y después de recibir varios impactos de cañón, el buque alemán pidió una tregua para trasladar al Arucas a los prisioneros ingleses capturados en los hundimientos anteriores y a la marinería propia. Cuando la refriega se dio por perdida los cañoneros alemanes abandonaron el barco y alcanzaron la orilla a nado, haciendo volar la santabárbara para provocar su hundimiento. ${ }^{8}$

La reacción del Gobierno español no se hizo esperar. El buque alemán había transgredido el artículo $2 . .^{9}$ del XIII Tratado de La Haya al no llevar senales exteriores de barco de guerra y el artículo $19 .{ }^{\circ}{ }^{10}$ del mismo al cargar

${ }^{3} A B C, 30-8-1914$

${ }^{9}$ Gaceta de Madrid. Núm. 318, 24-11-1914. Artículo 2.:- Todos los actos de hostilidad, comprendiendo en ellos la captura y el ejercicio del derecho de visita, cometidos por buques de guerra beligerantes en las aguas territoriales de una Potencia neutral, constituyen una violación de la neutralidad y están estrictamente prohibidos.

${ }^{10}$ Artículo 19.․: Los buques de guerra beligerantes no pueden avituallarse en los puertos o radas neutrales más que para completar su aprovisionamiento normal en tiempo de paz. Dichos buques no pueden tampoco tomar combustible más que para llegar al puerto más próximo de su propio país. Pueden, sin embargo, tomar el combustible necesario para llenar sus pañoles, propiamente dicho, cuando se encuentren 
carbón y provisiones sin permiso de las autoridades responsables de las aguas territoriales. Consideraba igualmente que los ingleses habían infringido el artículo 1.. ${ }^{11}$ y $2 .$. del mismo tratado al bombardear un barco, en vez de entregarlo a las autoridades españolas. Los alemanes rechazaron las acusaciones por considerlas no acordes con la interpretación del tratado de La Haya. Un informe del Almirantazgo alemán de finales de abril de 1915 exponía con detalle su punto de vista, manifestando que era un ardid de guerra no tener izada la bandera en un momento considerado crítico, además, para el oficial español que visitó el barco en la rada de Río de Oro y para otros oficiales que observaron desde tierra, no les cabía duda del carácter de éste. Su tripulación se vistió durante la carga del carbón con prendas no reglamentarias, aunque llevaban en sus gorras las insignias correspondientes. Una maniobra de aprovisionamiento en un único lugar, incluso proporcionada por varios barcos, no se podía considerar como una base de operaciones y en cuanto a la permanencia por más de 24 horas en el lugar tampoco podía ser considerada una violación de la neutralidad. Alemania se reservaba el derecho de utilizar el artículo $12 .{ }^{12}$ por el que se permitía la permanencia indefinida de barcos de guerra de los beligerantes en puertos y aguas territoriales neutrales mientras el estado correspondiente, en este caso España, no lo prohibiese con sus leyes internas.

La documentación consultada no informa si se llegó a algún acuerdo. Este caso, que puede servir de ejemplo para plantear otros similares, deja constancia de que los acuerdos de La Haya se podían interpretar fácilmente según las conveniencias de cada interesado. Los problemas se resolvieron, como se resuelven generalmente en las guerras, no por el respeto a unas normas establecidas, sino por el uso del poder y la influencia. Los procesos ante un tribunal de arbitraje se retrasaron sine die hasta que la mayoría se olvidaron. De todas formas hubo alguna excepción a esta costumbre aceptada, Alemania estudió las reclamaciones por el hundimiento de barcos neutrales y pagó algunas indemnizaciones después de la guerra por daños causados de forma injusta. ${ }^{13}$

en paises neutrales que hayan adoptado este modo de determinación del combustible que puede proveerse si, según la ley de la Potencia neutral, los buques no reciben carbón hasta después de 24 horas de su llegada, la duración legal de su permanencia se prolongará veinticuatro horas.

${ }^{11}$ Artículo 1.: Los beligerantes están obligados a respetar los derechos soberanos de las potencias neutrales y a abstenerse, en el territorio o en las aguas neutrales, de todos los actos que constituirian por parte de las potencias que los tolerasen una falta a su neutralidad.

${ }^{12}$ Artículo 12. En defecto de otras disposiciones especiales de la legislación de la Potencia neutral, se prohíbe a los navíos de guerra de los beligerantes permanecer en los puertos y radas o en las aguas territoriales de dicha Potencia durante más de veinticuatro horas, salvo en los casos previstos por el presente Convenio.

${ }^{13}$ CARDEN,Ronnje, German Policy toward Neutral Spain 1914-1918. Modern European History Serious, New York 1986 


\section{DIFICULTADES EN LA NAVEGACIÓN DE LOS MERCANTES ESPANOLES}

Al quedarse paralizados los frentes de batalla y haberse declarado la guerra de desgaste y agotamiento de las potencias centrales, los alemanes pensaron en seguir la misma táctica respecto a las islas Británicas, es decir, bloquear sus costas con ataques de los submarinos a todo el tráfico marítimo para disminuir los suministros vitales y provocar el agotamiento que les impidiese proseguir la guerra. Se fijó una zona de guerra alrededor de las islas Británicas, en la que tanto los barcos ingleses como los neutrales serían controlados y, en caso de transportar contrabando de guerra, hundidos junto con la carga.

En Alemania se manifestaron dos opiniones contrarias. El Alto Mando Militar apoyado por el Jefe del Almirantazgo, Hugo von Pohl, presionaba para poder utilizar al máximo la estrategia submarina y conseguir la victoria en el plazo más corto posible. El Gobierno, con su Canciller, Theobald von Bettmann Hollweg, al frente y apoyado por el Ministro de Asuntos Exteriores, Gottlieb von Jagow, exigía prudencia con el fin de evitar que los países neutrales, especialmente los Estados Unidos, se sintiesen excesivamente perjudicados y se viesen obligados a declararles la guerra.

En febrero de 1915 tuvo lugar la primera ofensiva de la flotilla submarina, aunque con instrucciones de atacar sólo a los barcos enemigos y respetar los neutrales. Los alemanes querían poner un freno psicológico al ingente comercio naval trasatlántico. Inglaterra disponía de 11.000 barcos mayores de 100 toneladas de registro bruto (TRB) contra los que Alemania oponía 20 submarinos, de los cuales sólo siete estaban en servicio activo. Después de algunos éxitos parciales, el 7 de mayo de 1915 fue hundido por un submarino alemán el trasatlántico inglés, blindado y armado, Lusitania, muriendo 413 tripulantes y 785 pasajeros, de los cuales 128 eran de nacionalidad estadounidense. Esto produjo una airada protesta de los países neutrales y el 1 de junio se dio orden de evitar a toda costa el ataque a los mercantes de los países neutrales. ${ }^{14}$

Al comenzar la contienda, el comercio internacional de España se desvió hacia los países de la Entente debido al bloqueo inglés del paso hacia las costas alemanas. Los envíos a Francia llegaron sin dificultad a su destino, sin embargo, los dirigidos a Inglaterra tuvieron que sufrir el control de los submarinos. El 17 de agosto de 1915 fue hundido el primer mercante español, Isidoro, por el submarino alemán U-38. España manifestó su protesta, pero el Jefe del Almirantazgo se justificó manifestando que a España se le daba el mismo trato que a cualquier otra potencia neutral. 2000.

${ }_{14}$ Para mayor información: SCHRÖDER, Joachim. Die U-Boote des Kaisers, Europaforum Verlag, Lauf, 
En España cambió el panorama político al hacerse cargo Romanones de la jefatura del Gobierno el 9 de diciembre de 1915. Los temores del Embajador alemán a que el Gobierno inclinase sus preferencias hacia los países de la Entente, quedaron un poco frenados por la nominación de Villanueva como Ministro de Estado, que simpatizaba con los Imperios Centrales. Sin embargo, sin ningún motivo que lo justificase, pidió a Alemania la cesión de diez barcos alemanes refugiados en puertos españoles, para resarcirse de los perjuicios que estaba causando la guerra submarina. ${ }^{15}$

Por su parte, Alfonso XIII, en febrero de 1916, tuvo una conversación con el agregado militar de la Embajada alemana, manifestándole que para salir del agobio a que le sometía Inglaterra al amenazar con que iba a reducir el suministro de carbón, había pensado sustituir estas importaciones por otras provenientes de Norteamérica. Para ello necesitaba más capacidad de transporte por mar y aportó como solución el poder utilizar los barcos alemanes internados en España, dando su palabra de que dichos barcos no serían utilizados para el comercio con las Islas Británicas. El Rey quería saber la posición de Alemania para, en caso positivo, dar luz verde al Gobierno para que concertasen los detalles. Ratibor, de acuerdo con esta propuesta de Alfonso XIII añadía en un comunicado a su Ministerio, que, en el caso de rechazar la propuesta, la presión de Inglaterra podía llegar a obligar a España a incautar los barcos. ${ }^{16}$

El ministro de Estado, Villanueva, tuvo que tomar el puesto de Ministro de Finanzas en febrero, quedándose Romanones con el Ministerio de Estado. Después de esta nueva situación menos favorable a los intereses alemanes, Ratibor veía con preocupación que cada día aumentaba más la inclinación del Gobierno hacia los aliados, se incrementaba el contrabando, se dificultaban las acciones alemanas antifrancesas en Marruecos y los ministros se dejaban influenciar cada vez más por las exigencias de Francia e Inglaterra, razones que le llevaron a proponer a sus superiores un endurecimiento de sus relaciones con el Gobierno español para equilibrar la presión aliada ${ }^{17}$. Jagow, Secretario de Estado alemán, contestó que en aquel momento se estaba intentando conseguir el consentimiento de las autoridades para el alquiler de los barcos, pero el cambio tan repentino del Ministro de Estado, sobre todo después de haber asegurado el Rey que Villanueva se mantendría en su puesto, había dado un giro a la situación, esperaba una señal que le convenciese de que las relaciones continuarían como hasta aquel momento. La decisión sobre la cesión de los barcos quedaba pospuesta a la espera de que el Káiser mandase una carta personal al Rey, carta que enviaría en

${ }^{15}$ En España estaban internados desde el principio de la guerra 3 veleros y 40 vapores alemanes con un registro de $117.523 \mathrm{TRB}$.

${ }^{16}$ AA PA, Spanien 61, Bd 5. 25-2-1916. Ratibor-AA

${ }^{17}$ AAPA, Spanien 61, Bd 5. 27-2-1916. Ratibor-AA 
submarino previsiblemente a principios de abril. De todas formas, Jagow recomendó a sus diplomáticos en España actuar con la máxima prudencia y afabilidad, evitando toda acritud en el trato personal. Dado que la situación geográfica de Alemania era completamente distinta a la de Inglaterra y Francia, cualquiera amenaza podía traer consecuencias muy graves. ${ }^{18}$

El 16 de marzo, Rosen, ex Embajador en Portugal, fue recibido por Alfonso XIII, quien le encargó trasmitir al Kaiser su buena disposición para intermediar entre las potencias beligerantes para conseguir la paz. También le recordó que la cesión de barcos internados ayudaria a paliar los daños de la guerra. El Káiser aprobó estas manifestaciones en las notas marginales del informe de Rosen. ${ }^{19}$

España siguió insistiendo en sus aspiraciones por medio del Embajador en Berlín, Luis Polo de Bernabé, quien reiteraba que España estaba muy necesitada de capacidad para el transporte marítimo y que en el caso de recibir los barcos, éstos sólo se usarían para el servicio de cabotaje o la navegación a América y los productos serían destinados al consumo interior de España y se exportarían sólo productos españoles. Si no fuese posible recibir todos los barcos internados, a España le interesaría adquirir, cuando menos, los adecuados para el servicio trasatlántico, es decir, veintisiete unidades con una capacidad de 134.000 toneladas. Los barcos serían comprados por el Estado español, una vez que Inglaterra asegurase que éstos no iban a ser detenidos por los cruceros británicos ${ }^{20}$. Ya a principios de mayo se redactó un borrador con las condiciones de la entrega de los diez barcos. En él se detallaba que los fletes se convendrían por un tiempo determinado y a los precios del mercado, los barcos serían devueltos después de la guerra, estarían asegurados contra destrucción o captura, el servicio se realizaría entre puertos españoles y neutrales, no pudiendo reemplazar a los que ya realizan este servicio, los productos transportados se destinarán al consumo español y se mantendrán lejos de la zona de guerra. ${ }^{21}$

\section{EL SUBMARINO U-35 EN CARTAGENA}

A principios del año 1916 las tropas alemanas de protección del Camerún decidieron a abandonar el país por la presión de las fuerzas francesas e inglesas. Tanto los soldados alemanes y sus familias, como las tropas indigenas a sus órdenes, se refugiaron en Guinea Española, siendo acogidas provisionalmente en Fernando Poo. Después de alguna polémica 900 alemanes fueron trasladados a España, llegando a Cádiz el 4 de mayo de 1916

\footnotetext{
${ }^{18}$ AAPA, Spanien 61, Bd 5. 1-3-1916. Ratibor-AA

${ }^{19}$ AAPA, Spanien 61, geh. Bd 1. 20-4-1916. Rosen-Bettmann Hollweg.

${ }^{20}$ AAPA, Spanien 61, Bd 5. 31-3-1916. Polo-Jagow.

${ }^{21} \mathrm{RAH}, \mathrm{AR} 30 / 241$ (20.6-5-1916, Polo-Gimeno.
} 
en buen estado de salud, sólo nueve militares fueron hospitalizados por padecer fiebre. En condiciones relativamente confortables fueron internados hasta el final de la guerra en cuatro ciudades españolas: Aranjuez, Pamplona, Alcalá de Henares y Zaragoza ${ }^{22}$. La noticia fue muy valorada por los alemanes, de ahí que el Káiser enviara, por medio de un submarino y manteniendo en secreto la operación para evitar posibles ataques aliados ${ }^{23}$, una carta personal al Rey Alfonso XIII, cuyo borrador era el siguiente:

\section{Mi querido Alfonso,}

Los saludos que me has enviado a través de mi enviado Dr. Rosen me han producido gran alegría y te los devuelvo. Es para mí una satisfacción ponerme en contacto contigo directamente a través de uno de mis submarinos. Su comandante tiene la orden de atracar en un puerto español tal como lo has deseado. Desde este punto el Oficial de Marina de mi Embajada te hará llegar mi carta.

Sobre todo deja que te dé las más expresivas gracias por la acogida tan cordial que has dispensado en España a los alemanes. Puedes estar seguro de que no olvidaremos nunca la ayuda recibida por el noble pueblo español a los alemanes que se encontraban en una situación tan angustiosa, tanto más porque sabemos lo que sufre tu precioso país por causa de la guerra. Me produce una alegría especial poder confirmarte a través de mi Embajador que, de acuerdo con tus deseos, he puesto a tu disposición diez barcos alemanes. Mi Gobierno se ha puesto de acuerdo con el tuyo para fijar las condiciones necesarias. Puedes estar seguro de que tienes la máxima comprensión de mi parte y está en lo más profundo de mi corazón la intención de facilitar, en todo lo que corresponda a mi persona, tu tan difícil cometido.

El Dr. Rosen me ha informado sobre tu idea de la situación de España durante la guerra mundial. Como tú sabes, no depende de nosotros el que se alargue tanto el estado de guerra. Ya el 9 de diciembre de este año mi Canciller ha declarado en el Parlamento que nosotros en todo momento estamos dispuestos a discutir las ofertas de paz de nuestros enemigos que correspondan a la dignidad y la seguridad de Alemania. Desgraciadamente parece que nuestros contrarios no han encontrado el camino para conocer la verdadera situación de las cosas. Sin embargo, ha de llegar el momento. Quizá te envíe la Providencia para colaborar en este asunto.

Te ruego le trasmitas a Ena mis saludos más cordiales y tú recibe con sincera amistad mi más cordial afecto.

Tu amigo y primo (firmado) Guillermo

Cuartel General del Ejército, a 5 de mayo de 1916

A S.M. el Rey de España. ${ }^{24}$

AAPA, GHQ, Spanien 38, Bd. 1, 10. 5. 1916, Ratibor-AA

${ }^{23}$ AAPA, GHQ, Spanien 38, Bd. 1, 25.4.1916, Treutler-AA

${ }^{24}$ AAPA, GHQ, Spanien 38, 5.5.1916, Guillermo II-Alfonso XIII. 
El día 21 de junio de 1916, sorprendiendo a todo el mundo, el submarino $U$-35 entró a las 4:30 de la madrugada en el puerto de Cartagena y atracó al costado del barco alemán Roma, refugiado allí desde el principio de la guerra. Antes de que empezase la actividad en el puerto entregó al Roma paquetes con medicamentos para los internados alemanes y escritos destinados a la Embajada de Madrid, recibiendo a su vez agua potable y aceites lubricantes. Asimismo embarcaron en el submarino nueve marineros alemanes de los barcos retenidos en Cartagena, para ser transportados hasta Cattaro y poder regresar a Alemania. A primera hora de la mañana el Comandante del apostadero de Cartagena invitó al U-35 a atracar al costado del crucero Cataluña, para estar mejor protegido y ocupar un lugar más visible para el público situado en el muelle. Al izarse la bandera del Catalu$\tilde{n} a$, el $U$-35 saludó con veintiún cañonazos que fueron contestados con otros tantos desde tierra firme. La tripulación del submarino fue agasajada por las autoridades de Cartagena y numeroso público estuvo visitando el submarino hasta la puesta del sol. El comandante del $U$-35 quedó muy complacido por los agasajos recibidos, hasta tal punto que recomendó repetir la visita y propuso conceder medallas al Capitán del Cataluña, al Comandante del Puerto, al Cónsul alemán y al Capitán del Roma. ${ }^{25}$

Sin embargo, para cierta prensa resultó enojoso que el submarino pudiese entrar en el puerto sin que nadie se diera cuenta y pudiese atracar al costado de cinco barcos alemanes que desde el principio de la guerra estaban allí retenidos ${ }^{26}$. Este asunto trajo consecuencias inesperadas para Alemania, la prensa española partidaria de Alemania informó con entusiasmo de la visita, mientras que la de tendencias aliadófilas criticó el hecho sin piedad. Los embajadores de Francia e Inglaterra en Madrid protestaron por la presencia del submarino en el puerto de Cartagena, en primer lugar por haber sido suministrado combustible y provisiones a un barco de guerra en plena actividad destructora y en segundo lugar por tratarse de un submarino, barco de guerra que no estaba considerado explícitamente como tal en los acuerdos de La Haya. Además, se reservaban el derecho de hacer una reclamación al Gobierno español «por todos los daños causados a los intereses británicos como resultado de las operaciones hostiles que el submarino ha podido emprender como consecuencia de las facilidades que se le han concedido " ${ }^{27}$. El Ministro de Estado, Amalio Gimeno, en contestación a estas cartas de protesta, indicó que se habían cumplido estrictamente los acuerdos de La Haya, tanto por parte del submarino como de las autoridades del puerto de Cartagena y declinaba toda responsabilidad sobre actuaciones de éste fuera de las aguas de soberanía española. Además, las notas aliadas carecían de base porque tanto franceses como ingleses igno-

${ }^{25} \mathrm{MA}, \mathrm{RM} 97 / 765,21.6 .1916$, Informe Arnault.

${ }^{26} \mathrm{RAH}$, AR $88 / 4(1), 23.6 .1916$, Montaldo-Brocas

${ }^{27} \mathrm{RAH}, \mathrm{AR}, 88 / 4(5)$. 1.7.1916, Vaughan-Romanones 
raban el motivo de la visita y el porqué los submarinos alemanes o austriacos no habían utilizado, hasta el momento, puertos neutrales para aprovisionarse. ${ }^{28}$

El agregado de Marina en la Embajada de Madrid, Krohn, comentó con posterioridad que la llegada del U-35 había caído como una bomba en los círculos del Gobierno español y había producido gran desasosiego entre los líderes políticos, sobre todo porque Francia sabía que la idea de esta operación había sido aprobada por Alfonso XIII. Tanto Gimeno como Romanones se habían mostrado contrarios a tal visita, aunque la considerasen dentro de toda legalidad. Durante una entrevista que el Agregado militar alemán tuvo con el Rey, éste manifestó su alegría por el buen éxito de la operación, pero mostró cierto temor por el peligro que suponía tal acción, ya que el enemigo en futuras visitas podía tomar medidas más rigurosas para evitarlas, a lo cual respondió el Agregado, que ciertos puertos españoles eran muy adecuados para entrar y salir los submarinos sin que pudiesen ser atacados por barcos de superficie enemigos. Incluso se había pensado organizar una línea de submarinos comerciales para suministrar a España los artículos que solamente fabricaba Alemania como medicamentos, colorantes, etc ${ }^{29}$. Esta proposición también se la hicieron al Gobierno a la cual éste respondió: «El Gobierno español no solamente ruega al Gobierno alemán que no envíe ningún submarino comercial, sino que desea que no se acerque ninguna clase de submarinos a los puertos españoles». Para tranquilizar a la opinión pública, aseguró Gimeno, que se habian dado instrucciones de evitar cualquier aprovisionamiento de submarinos. Asimismo el Embajador en Berlín, Polo de Bernabé, reiteró ante las autoridades alemanas que a pesar de que el Gobierno español consideraba a los submarinos como buques de guerra incluidos en los acuerdos de La Haya, no quería arriesgarse a admitir más submarinos alemanes en puertos españoles para evitar las reclamaciones de los aliados. ${ }^{30}$

\section{SEGUNDA OFENSIVA DE LA GUERRA SUBMARINA}

De febrero a mayo de 1916 tuvo lugar la segunda ofensiva de los submarinos alemanes, esta vez con mayor éxito, por disponer de un mayor número de unidades (47 submarinos, aunque algunos eran de la primera generación, diseñados para la defensa de las costas y no para combates en alta mar), en realidad la flota desplazada a la zona de bloqueo de las islas Británicas se componía solamente de 14 unidades. La mayoría de los ataques se realizaron según las normas de presas navales, es decir, navegan-

\footnotetext{
${ }^{28} \mathrm{RAH}, \mathrm{AR} 88 / 5(14), 5.7 .1916$, Gimeno-Hardinge.

${ }^{29} \mathrm{MA}, \mathrm{RM}$ 20/467, 22.8.1916, Krohn-Admiralstab.

${ }^{30} \mathrm{RAH}, \mathrm{AR} 8 / 4$ (7) 5. 10.7.1916, Gimeno-Polo.
} 
do el submarino en superficie, deteniendo el barco para comprobar su mercancía y, si se trataba de contrabando de guerra, arrojándola al mar o hundiendo el buque con su carga después de que la tripulación se hubiese alejado en sus botes salvavidas.

La relaciones hispano-alemanas se hicieron más tensas cuando, después de torpedear al trasbordador francés Sussex, los alemanes agredieron a varios mercantes españoles (Mar Caspio, Vigo, Ciscar y Aurora), lo que dio pie a Romanones para reclamar la cesión de los barcos con toda dureza y bajo la amenaza de romper las relaciones diplomáticas. Berlín no aceptó las demandas españolas, argumentando que las navieras españolas estaban haciendo el negocio de su vida, transportando suministros a Inglaterra, Francia e Italia, mientras que descuidaban los intereses nacionales, y ponía como condición para poder continuar con las conversaciones que estas navieras rescindiesen sus contratos en el más breve plazo que les permitiesen sus compromisos. ${ }^{31}$

Esta ofensiva terminó en el Atlántico cuando el Gobierno de los Estados Unidos protestó por las bajas de pasajeros norteamericanos que viajaban en navíos ingleses. Las reclamaciones comenzaron cuando el 23 de marzo de 1916 fue atacado el trasbordador Sussex, que fue confundido con un minador, como consecuencia de esta agresión murieron, entre otros, el compositor español Enrique Granados y su esposa que regresaban de Estados Unidos. El Gobierno norteamericano, al ver que el ataque se había realizado sin previo aviso a un barco de pasajeros, aunque éste finalmente pudo ser remolcado a puerto, sospecharon que los alemanes habían comenzado una guerra indiscriminada, y, en una nota de protesta, amenazaron con romper las relaciones diplomáticas si se volvía a producir un ataque similar. Alemania suspendió de nuevo la guerra comercial en gran escala en aguas británicas, trasladó parte de la flota submarina del Atlántico al Mediterráneo y allí continuó con los ataques a todo carguero sospechoso desde la base naval austriaca de Pola, hoy Pula al sur de la península de Istria (Croacia). Esta ofensiva obligó a los ingleses a evitar el paso por el canal de Suez y tomar la ruta de África del Sur.

En la guerra del Atlántico, Ir glaterra desarrolló un nuevo sistema de defensa, una trampa, contra los submarinos, que ya el 24 de septiembre obtuvo el primer éxito. Dicha trampa consistía en mostrar ante el submarino enemigo un barco pequeño que llevaba bandera de un país neutral. Al ser alertado por aquél, un cierto número de tripulantes se alejaban en botes salvavidas y creyendo que el barco ya había sido abandonado, el submarino alemán se acercaba para inspeccionarlo con más detenimiento. Cuando éste estaba a la distancia oportuna el barco inglés desplegaba su arma- 
mento y atacaba al submarino, al tiempo que otro submarino inglés unido al pesquero por un cable telefónico ya estaba preparado para atacar con contundencia al alemán ${ }^{32}$. Esta clase de ataques, junto con los de los barcos cargueros y de pasajeros blindados y armados obligaron a los alemanes a considerar muy peligroso el uso del sistema de presas navales, es decir, detener el barco para inspeccionar la carga, lo que dio lugar más adelante a la guerra indiscriminada, es decir, el ataque directo, incluso a los barcos neutrales, sin previo aviso.

En España el verano había traído una época de calma en las tensiones diplomáticas. Durante los meses de junio y julio de 1916 no fue atacado ningún barco español, en agosto fueron dos los mercantes hundidos, porque, según los informes alemanes, transportaban carbón a un puerto aliado ${ }^{33}$ y en septiembre el número de hundimientos se elevó a seis.

El Conde de Romanones anunció la apertura de las Cortes para finales de septiembre con la intención de poner sobre el tapete el problema de la carestía de carbón, principalmente el destinado a la industria y, a pesar de que también escaseaba en Inglaterra, la causa principal se fundamentaba en la falta de barcos para transportarlo de Inglaterra o Estados Unidos a la Península. Ratibor mientras tanto apremiaba a su gobierno para obtener antes de la apertura de las Cortes una respuesta positiva sobre la prometida cesión de los diez barcos alemanes internados. ${ }^{34}$

Alcalá Zamora filtró unas manifestaciones de Romanones en las que éste expresaba sus temores de tener que entrar en la guerra a favor de la Entente en una operación similar a la que había sucedido en Grecia. Esto asustó a Ratibor quien creyó necesario tomar medidas más duras para frenar los impulsos del Conde ${ }^{35}$, sin embargo, su Gobierno sólo le autorizó a hacer pública la oferta alemana de suministrar carbón a través de puertos neutrales e intentar desplazar a Romanones del Gobierno, pero sin comprometer a la Embajada, ya que podía herir el orgullo de los españoles, especialmente del Rey, si se demostraba que se mezclaba en los asuntos internos de España ${ }^{36}$. Por su parte, el Almirantazgo dio orden a sus submarinos de tratar a los barcos españoles con especial deferencia, respetar estrictamente las aguas territoriales españolas y tratar a las tripulaciones con la máxima consideración.

El hundimiento del frutero Luis Vives el 11 de septiembre de 1916 dio lugar a otra nota de viva protesta española, pidiendo que, como mínimo, se respetasen los barcos dedicados a la exportación de fruta, esencial para la economía levantina, a lo que Alemania adujo que todos los barcos eran tra-

\footnotetext{
${ }^{22}$ KEMP Paul. Die deutschen und österreichischen U-Boot-Verluste in beiden Weltkriegen. UrberVerlag, Gräfelfing, 1997. Págs. 15 y 280.

${ }^{33}$ AAPA, Spanien 61 geh. Bd. 2. 18-9-1916. Holzendorff-Jagow

${ }^{34}$ AAPA, Spanien 61 geh. Bd. 2. 5-9-1916. Ratibor-AA

${ }^{35}$ AAPA, Spanien 61 geh. Bd. 2. 8-9-1916. Ratibor-AA

${ }^{36}$ AAPA, Spanien 61 geh. Bd. 2. 11-9-1916. Jagow-Ratibor
} 
tados según la Declaración de Londres y las normas alemanas de presas navales, actuar de otra manera no era posible si se quería mantener el rendimiento de la lucha submarina ${ }^{37}$. El Embajador de Austria, en una conversación que tuvo con Alfonso XIII objetó que el Luis Vives transportaba plomo de las minas de Romanones, a lo que contestó el Rey: «si vous pouviez prouver cela, ce serait un coup de maitre». ${ }^{38}$

Alemania reaccionó ofreciendo salvoconductos que serían extendidos por sus cónsules, una vez comprobada la mercancía, para que sus submarinos no atacaran a los fruteros, pero con la condición de que Inglaterra dejase paso libre a los que se desplazasen a Holanda, con la intención de que fuesen reexportados a Alemania ${ }^{39}$. Inglaterra demoró la respuesta hasta enero de 1917, insistiendo en que el derecho internacional permitía visitar y capturar los barcos con salvoconducto enemigo, sólo por consideración a España renunciaba a ejercer ese derecho y aceptaba los salvoconductos ${ }^{40}$. En febrero, con el comienzo del ataque indiscriminado de los submarinos, los salvoconductos sólo pudieron ser extendidos para puertos de destino situados fuera de las zonas de guerra. ${ }^{41}$

\section{GUERRA SUBMARINA INDISCRIMINADA}

Después de la entrada en la guerra de Italia y Rumania a finales de agosto la situación en Alemania empeoraba. La petición de paz de los alemanes y el intento de mediación del Presidente Wilson de los Estados Unidos fracasaron por las condiciones inaceptables de los aliados. Fue entonces cuando Alemania pensó que la última posibilidad de desequilibrar la balanza a su favor consistía en declarar la guerra submarina indiscriminada, intentando el bloqueo de las costas inglesas para evitar la llegada de provisiones vitales a la población civil y de los recursos necesarios para la guerra. Los militares estaban a favor de esta posibilidad, sin embargo, el canciller Bettmann-Hollweg temía que si los países neutrales se veían básicamente perjudicados se volverían contra Alemania. Una decisión en tal sentido de sus vecinos Dinamarca, Holanda y de los potentes Estados Unidos sería fatal para el desenlace de la guerra y para la supervivencia de la dinastía. Sin embargo, en enero de 1917 el Canciller tuvo que plegarse a los deseos del mando militar, que fijaron como fecha del comienzo de la operación el 1 de febrero, para interceptar los envíos de trigo de Sudamérica. Esto significaba que los submarinos alemanes atacarían a todo buque mercante que circulase por las aguas alrededor de las islas Británicas, Azores y todo el Mediterráneo, con

\footnotetext{
${ }^{37}$ AAPA, Spanien 61 geh. Bd. 2. 27-10-1916. Jagow-Ratibor

${ }^{38}$ AAPA, GHQ 38. Bd 1+2, 4-10-1916. Jagow-AA/Pless.

${ }^{39}$ AAPA, Spanien 61 geh. Bd. 3. 22-10-1916. Ratibor-AA

${ }^{40}$ AAPA, Spanien 61 geh. Bd. 4. 13-1-1917. Ratibor-AA

${ }^{41}$ AAPA, Spanien 61 geh. Bd. 4. 30-1-1917. Ratibor-AA
} 
excepción de una franja de veinte millas alrededor de las costas de los países neutrales y un paso por el Mediterráneo hasta Grecia. Alemania concedió a España y a los Estados Unidos un paso seguro para los barcos de pasajeros que se dirigían a Inglaterra en las condiciones siguientes: "el puerto de arribada será Falmouth, la ruta pasará por el punto $50^{\circ} \mathrm{N}$ y $20^{\circ} \mathrm{W}$, llevarán diversas marcas con líneas blancas y rojas, un barco por semana llegará a Falmouth el domingo y saldrá el miércoles, no llevará contrabando definido en las listas alemanas. Los barcos de carga con fruta provistos de salvoconducto no tendrán problemas para llegar a Inglaterra, no así los que cargados de carbón salgan de aquellos puertos. ${ }^{42}$

Romanones reaccionó ante esta nueva dificultad escribiendo al Rey el 31 de enero la siguiente observación: «Me temo que si se reciben noticias de torpedeamientos de barcos nuestros con la pérdida de su tripulación se produzcan atentados contra los Consulados alemanes y todo eso exacerbará la pasión entre la prensa germanófila y aliadófila» ${ }^{43}$. El Gobierno español contestó el 6 de febrero al comunicado de Alemania a través de una nota en la que protestaba por "sustituir el derecho de captura por el de destrucción, que está fuera de todos los principios legales de la vida internacional y el eliminar de la forma anunciada la vida de los no combatientes, de los súbditos de una nación neutral como España, es contrario a aquellos otros principios observados por todas las naciones aún en los momentos de mayor violencia» ${ }^{44}$. El Embajador Polo a su vez protestaba por la ampliación de las zonas de guerra que impedían el tráfico marítimo directo a Fernando Poo y reducía la zona de pesca de las islas Canarias. En respuesta a estas notas Alemania rogaba se reconociesen sus motivos, ya que se trataba de una circunstancia excepcional del derecho de guerra, necesario para no poner en peligro su economía y forzar el final de la contienda.

Ratibor comunicó a sus superiores la gran preocupación que había en los círculos económicos españoles, especialmente en los que se referían a las zonas de cultivo de frutas y pidió soluciones para ayudar a los cosecheros levantinos. El Ministerio de Asuntos Exteriores alemán dio orden de no entregar salvoconductos a tres fruteros, pero a cambio, ordenó comprar su carga para fabricar conservas con ella, además de comprar naranjas por valor de un millón de marcos ${ }^{45}$. Aparte de eso ofreció el suministro de carbón a recoger en puerto alemán o danés por barcos españoles que no deberían navegar atravesando las zonas de guerra ${ }^{46}$ y la venta inmediata de un barco, a prueba, de los diez prometidos por el Káiser anteriormente ${ }^{47}$. Las gestiones

\footnotetext{
42 AA PA, Spanien 61, 30-1-.1917, Zimmermann-Ratibor

${ }^{43} \mathrm{RAH}, \mathrm{AR} 30 / 24$ (8. 31-1-1917, Romanones-Alfonso XIII

${ }^{44}$ El Imparcial. 8-2-1917

${ }^{45}$ AA PA Spanien 61 geh. Bd.4 5-2-1917. Zimmermann-Ratibor

${ }^{46}$ AA PA Spanien 61 geh. Bd.4 6-2-1917. Zimmermann-Ratibor

${ }^{47}$ AA PA Spanien 61 geh. Bd.4 16-2-1917. Welczeck-AA.
} 
realizadas por Ratibor dieron como resultado la compra de fruta en Valencia y Murcia por valor de 500.000 ptas. Para el transporte de esta fruta Ratibor pidió 750 vagones, de los que sólo pudo conseguir 60 en un lapso de cuatro semanas, por lo que temió que la fruta se perdiese. La elaboración de conservas tropezó con muchas dificultades: falta de fábricas adecuadas, escasez de hojalata, elevado precio del azúcar e insuficiencia de vagones para su transporte. Una comisión técnica que se reunió en Flix (Tarragona), donde los alemanes tenían una gran factoría de transformación química, propuso la extracción de alcohol, esencia, ácido cítrico y forraje como única manera de aprovechar los excedentes de fruta. Con la intención de estrechar las relaciones comerciales entre España y Alemania después de la guerra mediante el aprovechamiento de las frutas españolas, sobre todo de las naranjas, el Gobierno Imperial concedió medio millón de ptas para construir una fábrica en Valencia destinada a aprovechar la cosecha no vendida como fruta fresca y elaborar los productos derivados de ella. Otras cien mil ptas fueron enviadas a Canarias para tratar de solucionar el problema de los plátanos, pero allí las dificultades fueron aún superiores. Ratibor terminaba el informe de sus gestiones diciendo:

«...tendrá a bien reconocer cuanto trabajo y dinero ha empleado ya esta Embajada en pro de la acción intentada a favor de los cultivadores de fruta. Desgraciadamente no estoy en condiciones de vencer todas las dificultades que se oponen a su desenvolvimiento y de las cuales una de las mayores es la falta de vagones, sin la cual una suma mucho más fuerte habría podido ya ser gastada en las compras de naranja» 48 .

El otro problema pendiente, la cesión de los barcos alemanes internados, se complicó cuando corrieron rumores de que el naviero de Bilbao, Horacio Echevarrieta, había vendido sus barcos a través de un hombre de paja a Francia o Inglaterra ${ }^{49}$ y una orden de la Marina de Bilbao iba a dar permiso para vender a Inglaterra todos los barcos inferiores a 3.000 toneladas ${ }^{50}$. Esto dio lugar a que se rompieran las conversaciones sobre la entrega de barcos alemanes, ya que si se había previsto vender estos barcos, significaba que las necesidades de transporte de la marina española no eran tan precarias como se suponía. Además, la cesión de barcos podría servir de precedente para otras naciones neutrales. Como consecuencia, se suspendieron todas las conversaciones sobre la venta de barcos, compra de fruta, oferta de carbón desde Escandinavia, pero se ampliaron las zonas de pesca españolas en zonas de guerra y el comercio de España con Suiza a través del puerto francés de Cette. ${ }^{51}$

${ }^{48}$ RAH, AR 30/29. 8.4.1917, Ratibor-Gimeno

${ }^{49}$ Echevarrieta vendió sus últimos cinco barcos a la naviera La Palma de San Sebastián en Febrero de 1917. Díaz Morlán, Pablo, Horacio Echevarrieta. Editorial Lid, 1999, p. 112

${ }^{50}$ AA PA Spanien 61 geh. Bd.4 14-2-1917. Ratibor-AA

${ }^{51}$ RAH, AR 30/26. 8.3.1917, Polo-Romamones 


\section{ESPIONAJE Y SABOTAJE. EL SUBMARINO U-35 EN CALA SALITRONA}

Durante los años de la guerra, Madrid fue un centro del espionaje político y militar de las potencias beligerantes. Para el servicio de información militar de Alemania, era España, junto con Suiza, uno de los puestos más importantes de observación para los asuntos franceses. El agregado militar alemán comandante Kalle era el responsable de los servicios de información en España del Mando Supremo del Ejército, cuyo principal cometido eran los asuntos relativos a Francia. Por otro lado estaba el agregado naval capitán de corveta Hans von Krohn que se cuidaba de observar las fuerzas navales aliadas, especialmente la flota británica y su importante base de Gibraltar, la vigilancia del transporte marítimo aliado y neutral en interés de la guerra submarina y el avituallamiento clandestino de los submarinos y cruceros auxiliares alemanes desde puertos españoles. Ya existía una red de información con sus puntos estratégicos en Madrid, Barcelona, San Sebastián y Bilbao, cuando Wilhelm Canaris (que más adelante llegaría a Almirante y jefe del servicio de contraespionaje y que al final de la segunda guerra mundial, en 1945, sería ahorcado por conspirar contra Hitler) llegó en diciembre a Madrid, siendo capitán de navío, para ayudar al agregado naval de la Embajada. Al trasladarse parte de la flota submarina del Atlántico al Mediterráneo en 1915, fue necesario aumentar la infraestructura de apoyo, por lo que la primera actividad de Canaris fue la de ampliar la red de información en esta zona con tres puntos principales: Valencia, Cádiz y Cartagena. ${ }^{52}$

Una segunda actividad que culminó con éxito Canaris fue la organización del suministro de víveres, combustible, repuestos y munición para los submarinos alemanes cuyo radio de acción era el mar Mediterráneo y las islas Canarias. Haciendo valer su pasaporte chileno, se hizo pasar por especialista en la construcción naval y encargó a los astilleros de Horacio Echevarrieta una flota de pequeños barcos, que ya en enero de 1916, con tripulación española, empezaron a trabajar en las zonas cercanas al estrecho de Gibraltar. Desde entonces Canaris tuvo muy buenas relaciones con personalidades españolas, e incluso fue el principal valedor en Alemania cuando en los años veinte Horacio Echevarrieta montó en los astilleros de Cádiz una fábrica de torpedos y una línea de construcción de submarinos con la colaboración de importantes empresas alemanas.

La pasajera tranquilidad en España, después de la declaración de la guerra submarina total, se rompió, cuando el 16 de febrero de 1917 se descubrió que un submarino alemán había depositado en la cala Salitrona, cercana a Cartagena, una serie de cajas que contenían explosivos, detona-

${ }^{52}$ AbShAGEN, Karl Heinz. El Almirante Canaris. Espasa Calpe, Buenos Aires, 1952. 
dores y material para su manejo, cartas, propaganda impresa, fotografías y libros. El comandante del submarino informó a sus superiores que había colocado en el fondo de la bahía 35 sacos, sujetos por una cuerda de $4 \mathrm{~m}$. a una cadena que yacía en el fondo del mar a una profundidad de $14 \mathrm{~m}$., conteniendo 6 toneladas de «material S» distribuido en 902 cajas estancas. Para localizar el material se colocó una boya y como segundo recurso una cuerda que, sujeta a la cadena llegaba hasta la costa, donde se enterró. Dos oficiales fueron desembarcados, el uno, Fricke, en el lugar en que fueron depositados los bultos, junto con un pequeño bote de remos que escondió en la cueva de las Ratas, y el otro Kallen en las cercanías de Escombreras, para que informase a sus contactos en La Unión. ${ }^{53}$ Las boyas fueron descubiertas por los vigilantes costeros españoles y todo el material fue extraído por buzos y trasladado al cercano puerto de El Bolete, donde fueron reconocidos por el juez instructor Caravaca, teniente de navío, y otros técnicos militares. ${ }^{54}$ Los explosivos descubiertos ascendían a 1.700 kilos de tetralita, 8 bombas de latón cargadas con 1.000 kilos de tetralita, 884 espoletas, 864 detonadores y diversas herramientas para manejar este material. ${ }^{55}$

El descubrimiento se comentó en los periódicos y dio lugar a encontradas manifestaciones. El Almirantazgo alemán informó al agregado militar que este material estaba destinado a ser distribuido entre los barcos alemanes retenidos en América del Norte y del Sur para inutilizarlos en el caso de que hubiese peligro de ser requisados por el enemigo ${ }^{56}$ Para reponer las pérdidas que pudieran provocarse durante su traslado se envió una cantidad superior a la necesaria, aunque una pequeña parte estaba destinada a los barcos internados en España. Junto con los explosivos se enviaron escritos de contenido inofensivo, propaganda alemana, fotografías y películas de los escenarios de la guerra, libros de bolsillo para su traducción al español y otros papeles que no comprometían a nadie. Una caja fue llevada directamente a tierra por el oficial desembarcado, que contenía cartas y artículos de periódico con instrucciones para el agregado naval y para el enlace, pero escritos en tinta simpática. No se enviaron municiones ni ningún aparato para armas o aparatos de navegación, aunque sí se enviaron detonadores de acción retardada para hacer volar los explosivos. ${ }^{57}$

Alfonso XIII reaccionó de forma moderada. El material de propaganda y las cartas dirigidas a la Embajada fueron entregados por él personalmente al Embajador alemán, asegurando el Rey que seguiría manteniendo la política de neutralidad que había observado hasta aquel momento. Sin embargo, ante las manifestaciones del Embajador de que él no estuvo informado

\footnotetext{
${ }^{53}$ MA, RM 20/467, 14-2-1917, Informe Arnoldt

${ }^{54}$ El Imparcial, 22-2-1917

${ }^{55}$ Romanones, Conde de. Notas de una vida. Obras completas. Espasa Galpe, Madrid, 1947. Pag. 361.

${ }^{56}$ AAPA, WK 11 q, Bd. 3. 3-3-1917. AA-Ratibor.

${ }^{57}$ AAAP, WK 11q, 7.3.1917, Holtzendorf-Kalle.
} 
previamente de estas acciones, el Rey exigió que todas las actividades de la Embajada estuviesen bajo la responsabilidad directa de Ratibor, lo cual significaba una advertencia seria para los agregados militar y naval, que se suponía estaban implicados en el asunto. ${ }^{58}$

Estos agregados declararon a su vez que ellos no habían sido informados previamente de la acción del submarino y por lo tanto no habían tomado parte en el asunto. El desembarco del material se había efectuado en una operación secreta, porque España no deseaba que se airease la noticia de la presencia de submarinos alemanes en su costa, desde que el U-35 atracó en el puerto de Cartagena el año anterior ${ }^{59}$ Desde Berlín se dio una explicación similar al Embajador español, diciendo que en ningún momento pretendían atentar contra la neutralidad y la soberanía españolas. Continuaba el Ministro de Exteriores: «si el desembarco de estos objetos ha sido contrario a algunas leyes especiales de España, es preciso considerar que estas medidas han sido tomadas, desde un punto de vista puramente técni$\mathrm{co}$, por las autoridades de la Marina sin conocimiento de dichas leyes especiales.» ${ }^{60}$ Teniendo en cuenta que una pequeña parte del material había sido desembarcado y enterrado y más tarde destruido y que el material secreto ya había sido puesto a buen recaudo, los alemanes pudieron permitirse ciertas concesiones y por ello las consecuencias políticas directas pudieron ser atenuadas. Lo único negativo para Alemania fue la detención de algunos agentes alemanes que fueron encarcelados 0 expulsados ${ }^{61} \mathrm{El}$ Ministro de Estado, Gimeno, no creyó en la inocencia de la Embajada alemana y pidió la expulsión de todos sus miembros.

\section{DECRETO DEL GOBIERNO DE DATO CONTRA LA GUERRA SUBMARINA}

Una de las primeras acciones del nuevo Gobierno de Dato en junio de 1917 fue promulgar un decreto para restringir las actividades de los submarinos en aguas españolas, quizá cediendo a las presiones continuadas de la Entente. La causa directa de esta iniciativa fue la reparación del submarino alemán UC-52, que el 13 de junio entró en el puerto de Cádiz con averías en sus máquinas, se le había estropeado el reductor de accionamiento de las hélices, por cuya causa tuvo que ser remolcado por el cañonero Vasco Nuñez de Balboa hasta el arsenal de La Carraca, teniendo que permanecer allí durante al menos tres semanas para su reparación. ${ }^{62}$ Los aliados presionaron para que fuese internado hasta el final de la guerra, pero el Gobierno, de

${ }^{56}$ AAAP. GHQ. 3, 1.3.1917, Ratibor-AA-

${ }^{59}$ AAAP, WK 11q, 6.3.1917, Krohn-Admiralstab

${ }^{80}$ AAAP, GHQ Bd. 3, 19.3.1917, AA-Polo

${ }^{61}$ AAAP, GHQ Bd. 3, 18.3.1917, Ratibor-AA/Admiralstab.

${ }^{62}$ MA RM, 20/467, Bl 21, ..17.6.1917 Almiralität-Reichsmarineamt 
acuerdo con la XIII Convención de La Haya, decidió permitir reparar las averías para que estuviese en condiciones de alcanzar el puerto más cercano a su país o de algún aliado. Para poder salir se impuso la condición de que el submarino tendría que estar reparado antes del día 28 de junio y abandonar el puerto antes de las 24 horas siguientes y que se garantizase que no intervendría en ninguna acción de guerra en su recorrido hasta un puerto alemán o austriaco. Así se lo comunicó el embajador español en Berlín, Polo, al Ministerio de Asuntos Exteriores alemán ${ }^{63}$. De acuerdo con lo previsto, el submarino zarpó de Cádiz la noche del 28 al 29 de junio de 1917 y el Almirantazgo confirmó al Káiser que el UC 52 había llegado a su base de Cattaro, sin tomar parte en ningún ataque a barco enemigo. Alabó el excelente comportamiento, tanto del capitán del submarino, que fue quien dirigió las actividades necesarias para reparar el submarino y que éste se reincorporase a su unidad en el plazo indicado, como del Agregado de Marina Krohn que solucionó brillantemente todos los problemas diplomáticos ${ }^{64}$. Asimismo el Kaiser, por medio de su Embajador en Madrid, agradeció al Gobierno español la colaboración de todas las autoridades españolas en la rápida reparación del submarino, respetando las reglas de la neutralidad y mostrando las amistosas relaciones que unen España y Alemania. ${ }^{65}$

En la misma noche del 29 de junio se publicó el decreto por el que se prohibía la entrada de submarinos, tanto de guerra como comerciales, de las naciones beligerantes a los puertos españoles. Los que no tuviesen más remedio que hacerlo, serían retenidos hasta el final de la guerra, sea cual fuese la causa de su entrada en puerto. Submarinos de naciones neutrales podrían circular por aguas españolas, navegando en superficie y mostrando su bandera.

Los alemanes protestaron contra este decreto, alegando que en el preámbulo de la XIII Convención de La Haya, aprobada por España el 24 de noviembre de 1914, se precisaba que ninguna potencia neutral podía cambiar las reglas en el curso de la guerra, a no ser que quedase demostrado que la medida servía para salvaguardar sus propios derechos. Consideraban que el decreto era discriminatorio porque perjudicaba sólo a los alemanes, cuyos submarinos de guerra, en caso de avería en un lugar cercano a la costa española, no tenían otra salida que acogerse a la ayuda española, lo mismo que la prohibición de utilizar los puertos a los submarinos comerciales alemanes, única forma de transporte entre Alemania y España, pues los barcos de superficie de la Entente tenían completa libertad para llevar a cabo este cometido. El Gobierno de Alemania se reservaba el derecho de analizar cada caso, cuando un submarino se viese en la necesidad de entrar en un puerto por avería o peligro. ${ }^{66}$

\footnotetext{
${ }^{6}$ AA PA, Spanien 61, ..19.6.1917, ..Polo-Zimmermann, 20.6.1917, .Holtzendorf-AA

${ }^{64}$ AA PA, Spanien 61, ..26.7.1917, ...Holtzendorf-Wilhelm II

${ }^{65}$ AA PA, Spanien 61, ..3.9.1917, ...Ratibor-AA.

${ }^{66}$ MA RM, 20/467, BI 34, ...31.7.1917 ....Nota verbal AA-Polo.
} 
El 29 de julio entró en el puerto de La Coruña el submarino UB 23 con graves daños producidos por cargas de profundidad en una refriega con la marina inglesa. Al día siguiente fue conducido a El Ferrol, donde quedó internado de acuerdo con el decreto del 29 de junio. El Ministerio de Asuntos Exteriores alemán protestó por la medida, ${ }^{67}$ pero ante la falta de reacción del Gobierno español, el Ministerio de Marina alemán ofreció al Gobierno español el submarino UB-23 en la situación en que estaba, con todo su armamento, pero sin los torpedos por el precio de 1.348 .000 marcos, para solucionar los problemas económicos que tenía en aquellos momentos la Embajada alemana. ${ }^{68}$ España no aceptó la propuesta.

El 9 de septiembre de 1917 otro submarino alemán, el U-49, entró en el puerto de Cádiz con ligeras averías. Tras reparar unas abolladuras en el costado del casco, salió del dique y quedó atracado en el muelle de carbón, cerca de la salida del Arsenal con la intención de que quedase internado. Las relaciones entre los oficiales del submarino y los responsables del Arsenal fueron muy cordiales, hasta el punto que el capitán vivió en casa del Secretario General del Arsenal. El comandante del submarino dio su palabra, al declarar y así lo confirmó por escrito en presencia del Cónsul de Cádiz, que actuaba también de traductor, que permanecería en el puerto con su barco. En aquella ocasión, informado el Rey de esta circunstancia, dio su palabra a un oficial de la Embajada de Francia que el submarino no abandonaría el puerto. El Agregado Naval llegó a Cádiz y es posible que éste en confabulación con el Cónsul alemán y el comandante del submarino decidieran su huida. El 6 de octubre, un sábado a las 5,30 de la tarde, el submarino salió del puerto. Un barco del práctico, con un oficial y cuatro marineros salió en su persecución, pero el submarino no atendió a las voces del oficial para que se detuviese. Como consecuencia de tal suceso fueron destituidos el Comandante General del Apostadero y el General Jefe del Arsenal ${ }^{69}$ e inmediatamente el Gobierno español exigió la vuelta del submarino al puerto de Cádiz. El Ministro de Asuntos Exteriores, Marqués de Lema, escribió a Polo:

«...Creo inútil encarecer a V.E. la gravedad de la situación si el Gobierno alemán no ordena el inmediato regreso del submarino pues de lo contrario difícilmente podría borrarse la penosa impresión que este enojoso asunto ha producido al Gobierno de S.M. y a la opinión pública española y son incalculables las consecuencias que podrían originarse». ${ }^{70}$

Al evadirse el submarino, el Rey y sus oficiales se sintieron desprestigiados ante los representantes de Francia e Inglaterra. Con su huida el capitán

\footnotetext{
${ }^{67}$ AAAP, GHQ, Bd. 1, 21.8.1917, Ratibor-AA

${ }^{68}$ AA PA, Spanien 46, . . 18.9.1917, Eckardt-Welczeck

${ }^{69}$ RAH, AR 1/10. 5-11-1017. Montaldo-Romanones

${ }^{70}$ AA PA, Spanien 61, ...10.10.1917, ..Lema-Polo.
} 
del submarino había destruido la fe en el honor y la confianza de los oficiales de la Marina Imperial de Alemania. "¿Sería posible restituirla devolviendo el submarino?». Un gesto que entusiasmaría tanto a los estamentos militares como a la opinión pública española y si la orden viniese del Káiser, Jefe supremo de los Ejércitos, sería una señal de que a los oficiales alemanes se les exigía una completa honorabilidad. ${ }^{71}$ En diciembre, de nuevo el Rey reclamó una respuesta a sus manifestaciones anteriores, reincidiendo en que consideraba un agravio personal el haberse dejado poner en ridículo por un joven oficial de Marina. Como respuesta personal, el Rey renunció al honor de vestir el uniforme de la Marina Imperial de Alemania, ${ }^{72}$ el Gobierno exigió de nuevo el regreso del UB-49 a Cádiz, así como la expulsión del Agregado Naval Krohn. El 19 de enero de 1918 Alfonso XIII escribía una carta a Guillermo II en los siguientes términos:

«.... en este delicado y enojoso asunto que, no he de ocultarte, me produjo disgustos y sinsabores creándome una situación difíicil, sobre todo por haber sido anunciada esta evasión y haberme prestado yo a responder por la marina alemana. Conozco tus buenas disposiciones y no dudo que después de cambiar alguna impresión con mi Agregado Militar, habrás de encontrar la solución más digna y satisfactoria.» ${ }^{73}$

Como Alfonso XIII mostrase durante largo tiempo su indignación ${ }^{74}$ y España tuviese que soportar una nueva presión de los aliados, ${ }^{75}$ los alemanes pusieron a disposición de las autoridades españolas un submarino similar, que quedaría internado en el puerto de Pola (Austria) hasta el fin de la guerra bajo supervisión de oficiales españoles. El 7 de febrero de 1918 el Canciller Hertling comunicó a Polo el resultado de las investigaciones, de las cuales se deduce que el comandante del submarino negaba haber dado su palabra de honor de no huir del puerto de Cádiz:

...Le commandant allemand du sous-marin n'a pas donné sa parole d'honneur, ni pour lui même ni pour le bateau de ne faire aucune tentative de fuite. D'autre part les officiers de la marine espagnole, à la suite d'un malentendu, avaient gagné la conviction que cette parole d'honneur avait été donnée... Le Gouvernement Impérial, en regrettant profondément que la fuite du sous-marin ait causé certaine embarras au Gouvernement Espagnol...animé du désir de donner une nouvelle preuve de son sentiment de déférence et haute estime pour sa Majesté le Roi met à la disposition du Gouvernement de Sa Majesté le Roi d'Espagne un sous-marin d'une valeur égale au sous-marin B 49 et se déclare prêt à placer pendant la durée de la guerre ce bateau dans le port de Pola sous la surveillance permanente des autorités compétentes espagnoles. ${ }^{76}$

${ }^{71}$ AA PA, Sp 61 geh., .Bd. 4. 17.11.1917. Kalle-OHL

${ }^{72}$ AA PA, Spanien 55, . 16.12.1917. Lersner-AA

${ }^{73}$ AA PA, Spanien 61, . 19. 1.1918. Alfonso XIII-Wilhelm II

${ }^{74}$ AA PA, Spanien 55, ...16.12.1917, ..Lersner-AA

${ }^{75}$ AA PA, Spanien 61, . ..12.1.1918, ..Informe Kalle.

${ }^{76}$ AA PA, Spanien 61, .Bd. 10. 7.2.1918. Hertling-Polo. 
Después de las dos desapariciones de los submarinos de Cádiz, la estrella del Agregado de Marina de la Embajada alemana empezó a eclipsarse. En octubre, el Gobierno español solicitó su cese sin dar ninguna justificación concreta, simplemente declarándole persona non grata. A lo largo del otoño se descubrieron unas relaciones íntimas del Agregado naval con una espía francesa, que dieron lugar a que el Embajador considerase a su Agregado enfermo de los nervios y lo mandase a un balneario para que se recuperara ${ }^{77}$. Ratibor comunicaba a sus superiores que la causa oficial de la baja de Krohn no fue debida a sus gestiones para la liberación del submarino de Cádiz, sino a su grave falta de salud. ${ }^{78}$

\section{ÚLTIMOS FORCEJEOS}

A principios de noviembre de 1917 pasó la Presidencia del Consejo de Dato a García Prieto, con lo cual cambiaron otra vez las circunstancias: las Juntas Militares perdieron su influencia política y Alemania no pudo encontrar en España el apoyo que había recibido anteriormente. Sin embargo, a pesar de que el Presidente era liberal, gran parte del Gobierno pertenecía a la más pura y dura derecha, quizá debido al miedo a una política social y económica progresista o a la amenaza que podía significar la revolución rusa, ese año triunfante. ${ }^{79}$ Durante este mandato continuaron las notas de protesta ante el Gobierno alemán por haber ampliado las zonas de guerra, en las que se incluyeron las islas portuguesas del Atlántico y una gran franja en la costa occidental africana. Esto trajo como consecuencia que los barcos de vela que partían de América con rumbo a las Islas Canarias o a la Península y que se aprovisionaban en las islas Azores, Madera o Cabo Verde, no pudieran eludir atravesar la nueva zona acotada, es decir, que estaban expuestos al mismo peligro que los barcos que tocaban los puertos ingleses. ${ }^{80}$ De la misma forma se impedía a los pescadores canarios acceder a sus lugares habituales de pesca en la costa mauritana, con lo cual se agravaba el problema de subsistencias en las islas, que ya en aquel momento era bastante serio y, además, cortaba las comunicaciones directas con los territorios españoles del golfo de Guinea, donde aún quedaban internados soldados alemanes, obligando a los barcos a internarse en el Océano Atlántico, o sea, suprimiendo todo el tráfico de cabotaje y paralizando todo el comercio con Liberia. ${ }^{81}$ Alemania contestó concediendo una franja libre para los pequeños pesqueros canarios dentro de la zona de guerra, pero se mostró firme en la prohibición de que ningún carguero atravesase dicha zona. Las comunicaciones con el África central se deberían realizar con bar-

${ }^{7}$ AA PA, Spanien 61, ...11.12.1917, ...Ratibor-AA

${ }^{78}$ AA PA, Spanien 61, ...1.6.12.1917, ... Ratibor-AA

${ }^{79}$ MaRín, José M ${ }^{a}$. El liberalismo en la crisis del sistema parlamentario español, Tesis doctoral, 1987, p. 107.

${ }^{80}$ MA RM 5, 4072, ...5-1-1918 ...Polo-Bussche

${ }^{81}$ MA RM 5, 4072, ...4-2-1918, 9-2-1918 ...Polo-Bussche 
cos que tuviesen suficiente autonomía para evitar la zona de exclusión situada en la costa mauritana. En el caso de que España no dispusiese navíos adecuados, Alemania cedería hasta el final de la guerra uno de sus barcos internados para realizar este servicio. ${ }^{82}$

El 8 de enero el Embajador en Berlín, Polo, envió otra nota solicitando que los vapores españoles, reunidos en convoyes semanales, marcharan a Inglaterra con frutas o en lastre, para regresar con carbón a España, dándoles un tratamiento similar al de los buques hospitales que con distintivos de la Cruz Roja eran respetados sin reservas, ${ }^{83}$ a lo que el Almirantazgo contestó que era absolutamente imposible hacer excepciones al desarrollo de la guerra comercial tal como esta estaba planteada. ${ }^{84}$

Durante el último periodo de García Prieto, las tensiones generadas por las elevadas cifras de barcos españoles hundidos desde principios de 1918 y la gran presión ejercida por la Entente, fueron aliviadas en el interior por dos acuerdos comerciales con Estados Unidos y Francia. ${ }^{85}$ Las exportaciones de estos países estaban en aquellos campos que podían haber sido ocasión de carencias muy importantes en España y las exportaciones españolas aseguraron la financiación para pagar las importaciones y paliaron las necesidades del sector frutero. Por otro lado, Inglaterra siguió suministrando carbón.

De nuevo, el 24 de febrero de 1918 se produjo otro cambio de Gobierno, en cierto modo favorable a las expectativas alemanas, ya que fue elegido presidente Antonio Maura, conservador y partidario de la neutralidad. A pesar de que fue un gabinete de concentración, en el que intervenían conservadores y liberales, la política exterior quedó en manos de los conservadores, su Ministro de Estado fue Eduardo Dato, y los liberales fueron reservados para la política interior. Maura tomó iniciativas en ciertas cuestiones para aliviar los problemas que generaba la guerra.

Ante las dificultades a que estaba sometido el transporte marítimo español, el Gobierno suscribió un acuerdo con las navieras el 1 de junio de 1918, por el que éstas quedaban bajo el control del Gobierno, se distribuían los principales materiales a transportar, por ejemplo: 100.000 t de carbón de Inglaterra, 20.000 t de petróleo y 40.000 t de algodón de los Estados Unidos, 40.000 t de tabaco de Filipinas, 50.000 t de nitratos de Argelia y Chile, etc., se moderaron los fletes para cargas de interés nacional y éstos quedaron estables durante un periodo de seis meses. Esta medida trataba de equilibrar el tráfico comercial marítimo, pues generalmente los barcos se dirigían en cada momento al lugar que les ofrecía mejores precios, mientras que

\footnotetext{
${ }^{82}$ AA PA, Spanien 61, ...15-2-1918 Bussche -Polo

83 MA RM 5, 4072, ...8-1-1918 ...Polo-Bussche

${ }^{84}$ AA PA, Spanien 61, ...8-2-1918 Bussche -Polo

${ }^{85}$ Diario Universal, Los convenios comerciales 4-3-1918.
} 
mercancías esenciales permanecían en los puertos, por ejemplo en los norteamericanos ,en espera de su transporte a España. ${ }^{86}$

Después de violentas campañas de descalificación de significados políticos de uno u otro bando, en los tres primeros meses de 1918, Maura estaba decidido a serenar los ánimos y luchar contra todo extremismo, viniese del campo germanófilo o del francófilo, aún cuando uno de sus compañeros de gabinete, Romanones, a la sazón Ministro de Instrucción Pública, era uno de los principales inductores de estas campañas. El Gobierno estaba muy interesado en aparecer neutral, como mínimo en mantener las formas, aún cuando esto no se cumpliese por completo en la política seguida con respecto al comercio exterior. El 4 de julio de 1918 entró en vigor la llamada ley de censura por la que se prohibía la publicación de noticias contrarias al respeto debido a la neutralidad de España o a su seguridad y la publicidad que "deshonre o entregue al odio o al menosprecio a un Jefe de Estado, o un pueblo, Gobierno, Ejército o Representante diplomático extranjeros». Los periódicos podían circular libremente después de ser eliminado el texto censurado. ${ }^{87}$ Estas medidas tuvieron más valor simbólico que práctico, ya que la tensión había disminuido por el descenso de las actividades de espionaje y propaganda tanto alemanas como aliadas, sin embargo, quedaron en el ambiente, como generadores de inquietud, por un lado los compromisos comerciales contraídos con los aliados y por el otro los continuos ataques a barcos mercantes españoles.

Cuando la situación parecía ser de relativa calma, el hundimiento de un petrolero y la presión de los Estados Unidos, aprovechando que a partir de mediados de julio la situación de los alemanes en la guerra ya había tomado un curso decididamente negativo, provocaron complicaciones inesperadas. En un Consejo de Ministros en San Sebastián se tomó la decisión de enviar una nota al Gobierno alemán en la que se volvieron a recordar todos los problemas surgidos de la guerra submarina: el ataque a barcos bajo la protección del Gobierno en los que a veces viajaban diplomáticos españoles, el no dar ayuda a los náufragos lejos de la costa causando a veces su muerte, los perjuicios para los navieros españoles haciéndoles imposible la navegación, y, en general, la desaparición de cerca del $20 \%$ de la flota española a manos de submarinos alemanes. Con motivo de estos hechos y de haber violado la neutralidad y la amistad de España, se tomaba la decisión de que cada barco español hundido tanto en zona de guerra, como fuera de ella, a partir de la recepción de la nota, sería sustituido por un barco alemán internado en España. ${ }^{88}$ La prensa española comentó:

\footnotetext{
85 MA RM 5/ 3124, ...10-6-1918 ...Stefan-Admiralstab

${ }^{87}$ Gaceta de Madrid, Núm. 185, 4-7-1918.

${ }^{88}$ AA PA, Spanien 45, ..12-8-1918, ..Bussche-Lersner.
} 
«Encontramos naturalísimo deber del Gobierno, deber ineludible reclamar enérgica y categóricamente en cualquier caso en que sea hundido injustamente un buque español. $Y$ si entonces Alemania no diese las satisfacciones debidas, llegar hasta donde sea preciso, en defensa del honor de nuestra Patria. Pero pensamos al mismo tiempo que el honor de España no está en la bodega de un buque contrabandista.» 89

El Subsecretario de Estado alemán, Bussche, que mientras tanto había tomado contacto con el Almirantazgo, intentó a través de Polo un aplazamiento del ultimátum español y objetando que los barcos que navegaban dentro de la zona de guerra no podían ser respetados por tácticas inherentes a la contienda (muchos barcos mercantes iban armados y el submarino tenía que atacar por sorpresa). Los que navegaban fuera de la zona guerra y transportaban productos alimenticios y materias primas podían navegar libres de todo peligro si llevaban salvoconducto, además, los comandantes de los submarinos alemanes tenían orden de respetar rigurosamente las aguas territoriales españolas y fuera de elias no atacar a los barcos españoles siempre que no transportasen contrabando de guerra. Alemania ofrecía indemnizaciones para los barcos hundidos o dañados injustificadamente, pero exigía esperar la decisión de un tribunal alemán. ${ }^{90}$

El 29 de agosto de 1918 fue hundido el vapor Atxerri Mendi, pero el Consejo de Ministros no decidió seguir una conducta firme y la amenaza de sustituir los barcos hundidos por otros internados no se hizo realidad. El 13 de septiembre fue informado oficialmente el Ministerio de Asuntos Exteriores alemán de la decisión del Gobierno español de no hacer uso del ultimátum del 14 de agosto.

En España, tanto Ratibor como el nuevo agregado naval, Stefan, estaban interesados en la cesión de los barcos a España para mejorar unas relaciones que, a medida que los alemanes veían el final desfavorable de la guerra, pudieran evitar un excesivo acercamiento de España a la Entente e, incluso, aprovechasen las buenas relaciones existentes generadas durante la guerra para conseguir mejorar los intercambios comerciales una vez alcanzada la paz, circunstancia importante, ya que España era el país neutral mayor de Europa. Alemania se resistía a la entrega de los barcos por falta de unidad de criterios entre los distintos departamentos, el Ministerio de Asuntos Exteriores, el Mando General del Ejército y el Almirantazgo, sin embargo, cedió y Ratibor confirmó el encargo de su Gobierno, el 27 de septiembre, de poner a disposición de España seis buques en alquiler hasta el fin de la guerra. Los detalles se fijarían mediante negociaciones con un perito naval español en Berlín. ${ }^{91}$

${ }^{89}$ ABC, El Día, La neutralidad española. 18-8-1918.

${ }^{90}$ AA PA, Spanien 38, ..14-8-1918, ..Bussche-Berckheim.

${ }^{91}$ AA PA, Spanien 61, 4-10-1918, Ratibor-Maura 
Cuando Maura el 10 de octubre hizo llegar a Ratibor un ultimátum en el que, en el término de una semana, tenía que dar una solución para reponer las 15.500 TRB de barcos españoles hundidos desde el 14 de agosto (Carasa, Atxerimendi, Francolí, Mercedes y María), ${ }^{92}$ apenas obtuvo resistencia, el mismo día Guillermo II dio su consentimiento para aumentar la cesión de cinco barcos prometida el 29 de septiembre con otros cinco más. ${ }^{93}$ Ratibor cedió oficialmente siete barcos (Eriphia, Euphemia, Petschili, Klio, Mathilde, Imfried, und Rudolf) con 21.000 TRB el 14 de octubre, uno de los cuales se consideró para reponer un barco hundido de forma ilegítima y el resto como ayuda a España, sin embargo, los ingleses no aceptaron la transmisión de propiedad, ya que ésta tenía que confirmase en la Conferencia de $\mathrm{Paz},{ }^{94}$ mientras tanto, si los descubrían navegando serían hechos prisioneros. En enero de 1920, los aliados permitieron que España retuviese los siete barcos cedidos por Alemania, que fueron rebautizados con los nombres España I a VII.

Mientras tanto en Europa el 3 de marzo de 1918 se firmaba el acuerdo de paz de Brest-Litowsk y el 7 de mayo el de Bucarest, dando por terminada la guerra en el este. En el frente belga-francés del 8 al 11 de agosto tuvo lugar la batalla de Amiens en la que los tanques ingleses destrozaron las líneas alemanas, fue un día negro para el ejército alemán, según expresión de Ludendorff, y en septiembre el frente retrocedió hasta la línea Sigfrido. Tras plantear Wilson sus 14 puntos para la paz, los generales Hindenburg y Lüdendorf pidieron un alto el fuego, en noviembre estalló la revolución en varias ciudades. Kiel, Munich y Berlín, el 11 del mismo mes los contendientes llegaron a un acuerdo de tregua en Compiègne y el 18 de enero de 1919 comenzó la conferencia de paz de Versalles.

El rápido desarrollo de los acontecimientos en los últimos días de lucha y las complicadas conversaciones de paz desviaron el interés de Alemania por los problemas españoles y, como consecuencia, las relaciones fueron cada día más escasas. A partir del 11 de octubre los submarinos alemanes ya no volvieron a atacar a ningún barco español, las críticas basadas en los hundimientos fueron sustituidas por las manifestaciones de los aliadófilos que se ensañaron con los vencidos. El 30 de octubre dimitió el Ministro de Estado, Dato, como protesta por el acuerdo de los barcos pero alegando motivos de salud. Con el empeoramiento de la marcha de la guerra para las potencias centrales las simpatías de los españoles cambiaron de rumbo y se orientaron hacia los aliados. Esta fue una de las causas por las cuales cayó el gobierno de Maura el 7 de noviembre. El nuevo Presidente del Consejo fue García Prieto, que en el discurso de su programa hizo alarde de sus

${ }^{92}$ AA PA, Spanien 61,..10-10-1918, Maura-Ratibor-

${ }_{93}$ AA PA, GHQ, Bd. 4. 10-10-1918. Grünau- AA

${ }^{94}$ AA PA, Spanien 61, 6-11-1918, 20-11.1918 Ratibor-AA. 
méritos por su actuación a favor de la Entente. Otro cambio de Gobierno el 5 de diciembre dio la Presidencia al Conde de Romanones, que, además, se reservó el Ministerio de Estado, entonces, en palabras del Conde, «llegó la hora del desquite. Bien me lo había ganado. Una vez más en la vida la justicia inmanente se imponía. Y viene esto a cuento ante la satisfacción que experimenté al comunicar al Príncipe Max de Ratibor que precisaba que en plazo muy breve saliera de Madrid. Y mi satisfacción fue mayor cuando me rogó le otorgase un plazo de ocho días para preparar su viaje, y otro más largo para que la princesa y su familia permaneciesen en Madrid. ${ }^{95}$ El Gobierno español declaró persona non grata al embajador Ratibor, al secretario de la legación Stohrer, al agregado militar Kalle, al agregado naval Stefan y al asesor de marina Grimm, que abandonaron el país el 9 de enero de 1919. El Conde de Bassewitz, secretario de la embajada, se hizo cargo de los negocios de ésta.

\section{CONCLUSIONES}

La opinión pública española durante la guerra se dividió en dos bandos, con fuerzas equilibradas, a quien llamaron germanófilos y francófilos o aliadófilos, aunque quizá la denominación más correcta de la mayoría hubiese sido germanófobos y aliadófobos, porque sus reacciones estaban dictadas más por una animadversión, generalmente de origen histórico, que por unas simpatías provocadas por unos intereses comunes. A lo largo de todo este periodo ambos bandos hicieron un gran esfuerzo por mantener la opinión pública de su parte y poder contrarrestar cualquier decisión que pudiese inclinar la balanza de forma decisiva a favor de uno u otro. Para ello ambos contendientes invirtieron grandes cantidades de dinero para dominar la prensa y modificar el comportamiento de políticos e intelectuales.

Los políticos con influencia en el Gobierno se decantaron por la neutralidad, porque nadie quiso correr el riesgo de aliarse con el perdedor de la lucha, ya que las consecuencias hubiesen sido catastróficas para España. Muchos españoles esperaban que Alemania saliese vencedora, pero cuando la estrategia desplegada por aquélla para conseguir una victoria rápida quedó frenada, sus esperanzas quedaron a la expectativa y los deseos de intervenir en la contienda sólo fueron mantenidos por una minoría carlista, herederos de las luchas del siglo anterior.

En los varios gobiernos de la época que nos ocupa, sólo hubo una personalidad que tenía fe en el triunfo de los aliados y pretendió con su adhesión conseguir algo más de prestigio para España en el concierto internacional. Éste fue el Conde de Romanones, que por tradición familiar se

\footnotetext{
${ }^{95}$ Conde de Romanones, Notas de una vida. Obras completas. Espasa Calpe, Madrid, 1947 Pag 382.
} 
sentía unido a Francia y personalmente consideraba que había que continuar con las relaciones a veces tirantes, a veces amistosas, con los países de nuestro entorno, Francia e Inglaterra.

Una vez planteada la estrategia del conflicto, ninguna potencia beligerante estuvo interesada en obtener la ayuda española, por considerarla muy exigua y sin valor para decidir nada que tuviese significación en el transcurso de la guerra, sin embargo, ambos bandos se esforzaron por que España se mantuviese neutral.

España permaneció neutral militarmente, pero su comercio se dirigió casi en exclusiva a los países aliados y prosperó de manera significativa suministrando materias estratégicas para la guerra. Uno de los problemas que tuvo bastante incidencia en las relaciones hispano-alemanas surgió cuando los barcos españoles, a pesar de ser neutrales y como consecuencia con derecho a ser respetados, fueron interceptados y agredidos por los submarinos alemanes cuando navegaban por la zona de guerra alrededor de las islas británicas. El número de ataques se puede cifrar en 128 y las pérdidas de la flota en un $20 \%$. También los barcos de guerra aliados detuvieron mercantes españoles cuando iban navegando hacia un país neutral pero con la sospecha de que su destino final fuese Alemania. Para suavizar las tensiones producidas por estos ataques se pensó en la cesión temporal de algunos de los barcos alemanes que como consecuencia de temer ser atacados por la armada británica quedaron internados en puertos españoles. El Ministro de Exteriores, Villanueva, pidió la cesión de diez barcos. Durante toda la guerra se prolongaron las protestas por el hundimiento de los barcos y las amenazas de incautarlos, a veces inducidos por las presiones de los aliados, pero el Gobierno alemán no encontró el momento oportuno para hacer realidad la promesa del Káiser, hasta que tuvieron la certeza de que habían perdido la guerra, entonces, tras un ultimátum de Maura, se entregaron siete barcos. En España siempre rondó la sombra del ejemplo de Portugal, que decidió incautar los barcos alemanes internados en el país a lo que Alemania contestó con la ruptura de las relaciones y la consiguiente declaración de guerra.

Las fricciones más importantes fueron protagonizadas por Romanones que creía ver en una alianza con Francia la consecución de sus sueños de que España fuese uno de los países ganadores de la guerra y en el reparto empezase a considerársele como una potencia europea. La realidad fue bien distinta, a España le horrorizaba la guerra, Francia resistía a duras penas e Inglaterra con el respaldo que podía ofrecerle los Estados Unidos no estaba interesada más que en conservar el statu quo, que por lo que respectaba a España consistía en el dominio, no compartido por otras potencias, del estrecho de Gibraltar.

El antagonista fue Ratibor, embajador de Alemania en Madrid. Su empeño principal estribó en mantener la neutralidad de España a toda costa, utilizando todos los medios a su alcance para conseguirlo. El único enemigo a 
quien se enfrentó públicamente fue Romanones y su arma principal fue la prensa. Luchó por que España se mantuviese neutral y consiguió su empeño, triunfó sobre Romanones en 1917, pero éste se desquitó expulsándolo del territorio español cuando Alemania perdió la guerra. De sus otras actividades algunas tuvieron éxito como el servicio de espionaje para informar a los submarinos sobre las rutas de los cargueros rumbo a Inglaterra o el abastecimiento de los submarinos alemanes alejados de sus bases por medio de pequeños barcos que se proveían en España. Otras fracasaron totalmente como los intentos de sabotear el envío de suministros a los países aliados dentro del territorio español. Después de la guerra las relaciones entre Alemania y España quedaron bastante paralizadas, pues los problemas internos absorbieron en ambos países todas sus energías. 


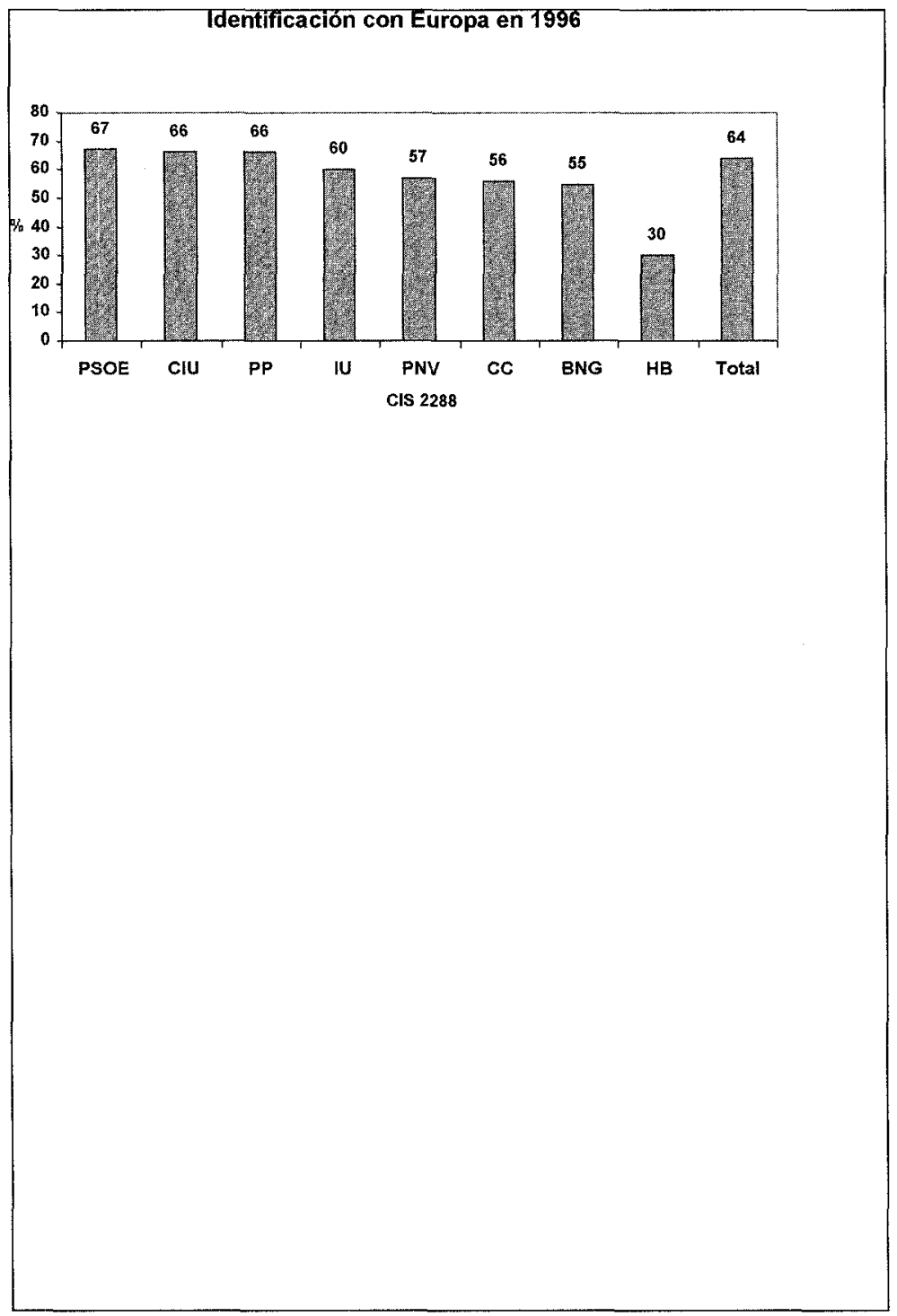

Figura 1.

Príncipe Max de Ratibor, Embajador de Alemania en Madrid. 


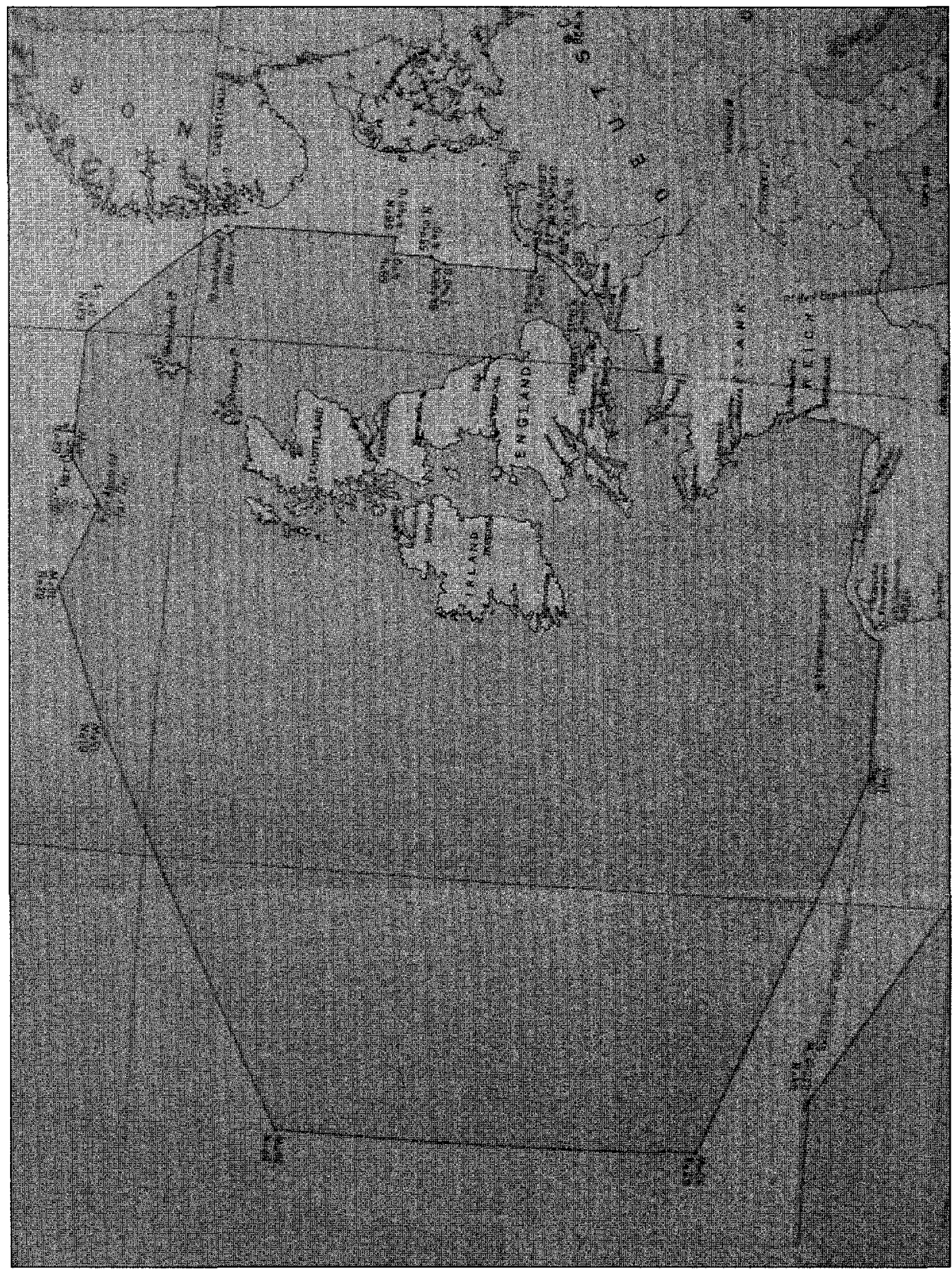

Figura 2.

Zona de ataque indiscriminado de los submarinos alemanes en 1918. 


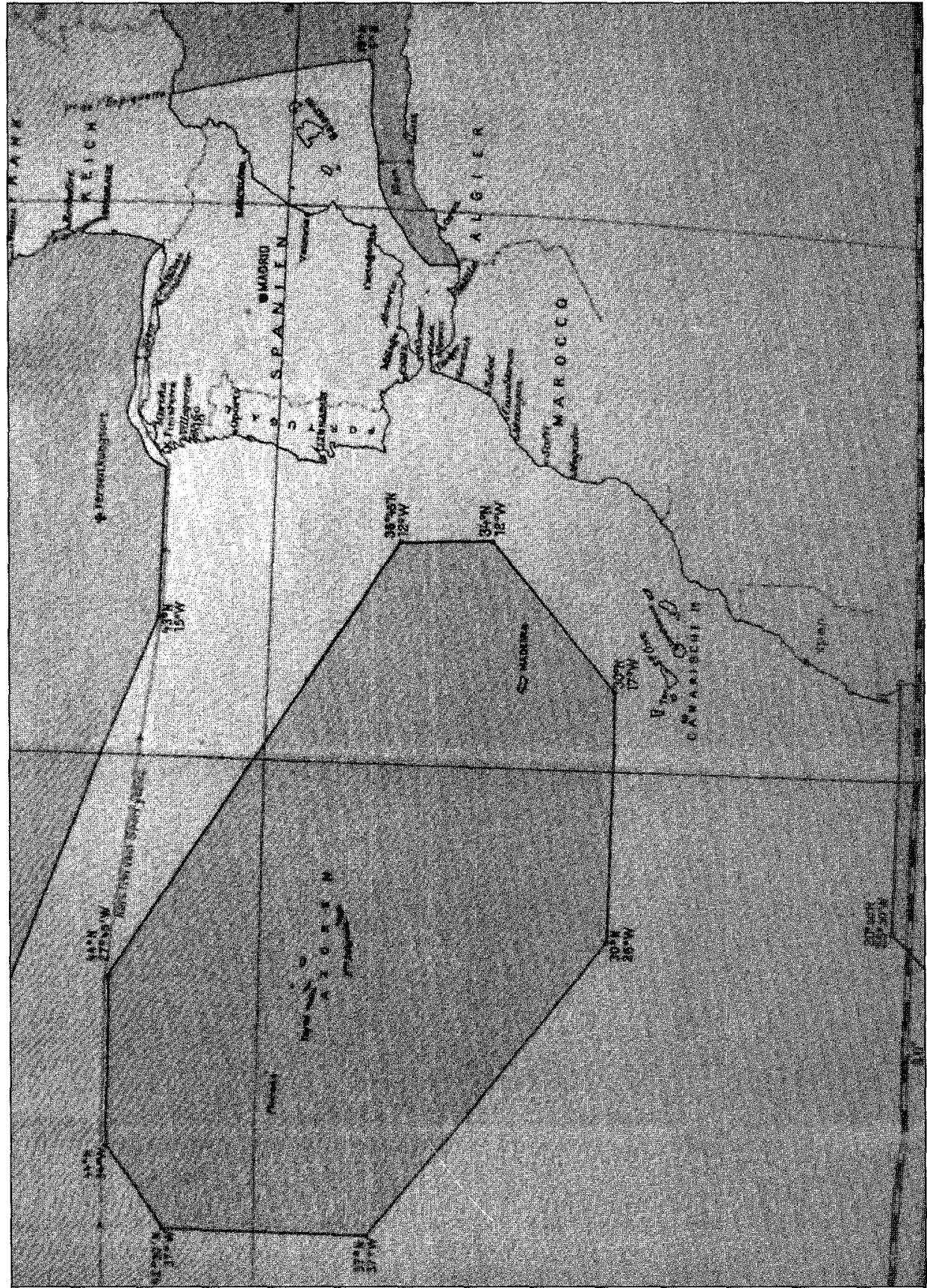

Figura 3.

Zona de ataque indiscriminado de los submarinos alemanes en 1918 


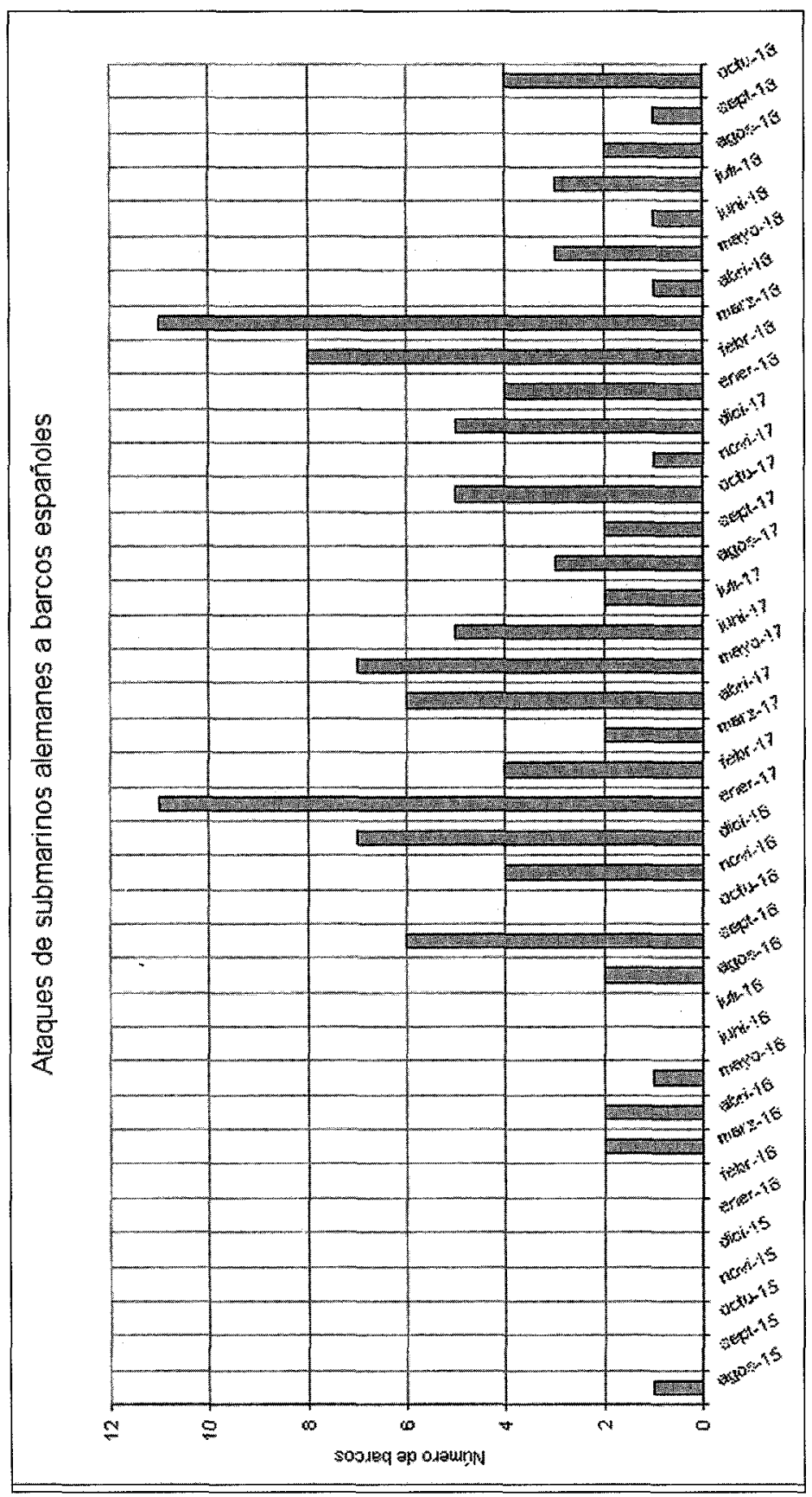

Figura 3.

Zona de los ataques indiscriminados de los submarinos alemanes en 1918. Entorno inglés. 